\title{
Invited review: overview of new traits and phenotyping strategies in dairy cattle with a focus on functional traits
}

\author{
C. Egger-Danner ${ }^{1 \dagger}$, J. B. Cole ${ }^{2}$, J. E. Pryce ${ }^{3}$, N. Gengler ${ }^{4}$, B. Heringstad ${ }^{5}$, A. Bradley ${ }^{6,7}$ and \\ K. F. Stock ${ }^{8}$ \\ 'ZuchtData EDV-Dienstleistungen GmbH, Dresdner Str. 89/19, A-1200 Vienna, Austria; ${ }^{2}$ Animal Genomics and Improvement Laboratory, ARS, USDA, 10300 \\ Baltimore Avenue, Beltsville, MD 20705-2350, USA; ${ }^{3}$ Department of Environment and Primary Industries, La Trobe University, Agribio, 5 Ring Road, Bundoora, \\ Victoria 3083, Australia; ${ }^{4}$ University of Liège, Gembloux Agro-Bio Tech (GXABT), Animal Science Unit, Passage des Déportés 2, B-5030 Gembloux, Belgium; \\ ${ }^{5}$ Department of Animal and Aquacultural Sciences, Norwegian University of Life Sciences, PO Box 5003, N-1432 Å, Norway, ${ }^{6}$ Quality Milk Management Services \\ Ltd, Cedar Barn, Easton Hill, Easton, Wells, Somerset, BA5 1EY, UK; ${ }^{7}$ University of Nottingham, School of Veterinary Medicine and Science, Sutton Bonington \\ Campus, Sutton Bonington, Leicestershire, LE12 5RD, UK; ${ }^{8}$ Vereinigte Informationssysteme Tierhaltung w.V. (vit), Heideweg 1, D-27283 Verden, Germany
}

(Received 2 April 2014; Accepted 11 September 2014; First published online 12 November 2014)

For several decades, breeding goals in dairy cattle focussed on increased milk production. However, many functional traits have negative genetic correlations with milk yield, and reductions in genetic merit for health and fitness have been observed. Herd management has been challenged to compensate for these effects and to balance fertility, udder health and metabolic diseases against increased production to maximize profit without compromising welfare. Functional traits, such as direct information on cow health, have also become more important because of growing concern about animal well-being and consumer demands for healthy and natural products. There are major concerns about the impact of drugs used in veterinary medicine on the spread of antibiotic-resistant strains of bacteria that can negatively impact human health. Sustainability and efficiency are also increasingly important because of the growing competition for high-quality, plant-based sources of energy and protein. Disruptions to global environments because of climate change may encourage yet more emphasis on these traits. To be successful, it is vital that there be a balance between the effort required for data recording and subsequent benefits. The motivation of farmers and other stakeholders involved in documentation and recording is essential to ensure good data quality. To keep labour costs reasonable, existing data sources should be used as much as possible. Examples include the use of milk composition data to provide additional information about the metabolic status or energy balance of the animals. Recent advances in the use of mid-infrared spectroscopy to measure milk have shown considerable promise, and may provide cost-effective alternative phenotypes for difficult or expensive-to-measure traits, such as feed efficiency. There are other valuable data sources in countries that have compulsory documentation of veterinary treatments and drug use. Additional sources of data outside of the farm include, for example, slaughter houses (meat composition and quality) and veterinary labs (specific pathogens, viral loads). At the farm level, many data are available from automated and semi-automated milking and management systems. Electronic devices measuring physiological status or activity parameters can be used to predict events such as oestrus, and also behavioural traits. Challenges concerning the predictive biology of indicator traits or standardization need to be solved. To develop effective selection programmes for new traits, the development of large databases is necessary so that high-reliability breeding values can be estimated. For expensive-to-record traits, extensive phenotyping in combination with genotyping of females is a possibility.

Keywords: phenotypes, novel traits, dairy cows, functional traits, genomics

\section{Implications}

The advances that have been made in breeding goals have been based on the needs of breeders; however, they are also influenced by consumers and societal needs related to food safety and efficient and environmentally sound production

\footnotetext{
${ }^{\dagger}$ E-mail: egger-danner@zuchtdata.at
}

systems. New functional traits are growing in importance because of recent declines in animal health and fitness. There is also growing competition for high-quality, plant-based sources of energy and protein; thus, it is important to use those resources very efficiently in animal production. Successful programmes for animal improvement will require a balance between the effort needed to record data and the resulting benefits to farmers. 
Egger-Danner, Cole, Pryce, Gengler, Heringstad, Bradley and Stock

\section{Introduction}

As a consequence of negative genetic correlations between milk yield and fitness traits, a decline in many functional traits has been observed (e.g. Jones et al., 1994; Lucy, 2001). In recent years, there has been a stabilization or even increase in genetic trends of functional traits (e.g. Miglior et al., 2012; ZuchtData, 2014). An example for the increase in genetic trend for longevity is shown for Holstein Friesian in Figure 1 (Fuerst C., 2014, personal communication). Herd management has been challenged to compensate for antagonistic effects and to balance selection for production while maintaining fertility, udder health and resistance to metabolic diseases in order to maximize profit without compromising welfare. As a result, there is increasing demand around the world for novel traits that can be used for herd management and genetic improvement, as well as for monitoring parameters of public interest.

The work needed to record additional data must provide immediate benefits to the producer in order to motivate the extra effort required. Individual producers place particular value on tools that can help them better manage their herds. If other stakeholders, such as veterinarians, are to be encouraged to record, for example, treatments and diagnoses, they also need to accrue benefits from the effort that they put in. As it is more and more challenging to balance high levels of production with reproduction and health, there is a growing need for data that can be used to detect problems at an early stage so that early interventions can be made.

The inclusion of functional traits in genetic improvement programmes is important for the long-term development of dairy populations. Genetic gains are cumulative, and small improvements that build up over time will provide ongoing savings to all farmers, particularly those using selection indices to combine information from many different traits. In response to these needs, there has been a worldwide shift towards more emphasis on functional traits in selection programmes over the past 15 years. Complex breeding goals that include up to 43 functional traits/country are encompassed by total merit indices
(TMI) according to a survey carried out by ICAR in 2012 (Stock et al., 2012), and the responses from 23 countries showed that genetic evaluations for calving ease, fertility, longevity, feet and legs and indirect health traits are very common. However, a wider range of health traits are actually being recorded, and there are plans in a number of countries to further expand their recording programmes to include additional reproduction, metabolic and efficiency traits. Public interest in the use of parameters for monitoring food safety, tracking disease outbreaks and documenting animal welfare is increasing. National monitoring programmes may therefore be developed to meet the demands of producers, consumers and regulators. The objectives of this paper are to give an overview of expected developments and challenges related to the availability of novel traits, with emphasis on new health and fitness traits in the near future, and to suggest strategies for phenotyping of new traits.

\section{Background}

The world population is estimated to reach 9 billion people in 2050 according to the latest demographic reports from the United Nations (2014), which will require a big increase in food production. Demand for limited resources will increase and prices for energy and concentrates will rise. Disruptions in global environments due to climate change (see, e.g. Walthall et al., 2012) may also drive a greater emphasis on novel traits, especially those that optimize resource use efficiency. Cattle producers will be challenged to find ways to reduce greenhouse gas emissions throughout the production cycle, either by increasing production efficiency and reducing wastage or by using new technologies to decrease pollution. In this context, there is need for novel traits that can be used in herd management and breeding. Functional traits, such as direct information of cow health, have also increased in importance because of growing concerns about animal welfare and consumer demands for healthy and natural products. Consumers are also concerned about the impact of drugs used in veterinary medicine on the spread of antibiotic-resistant

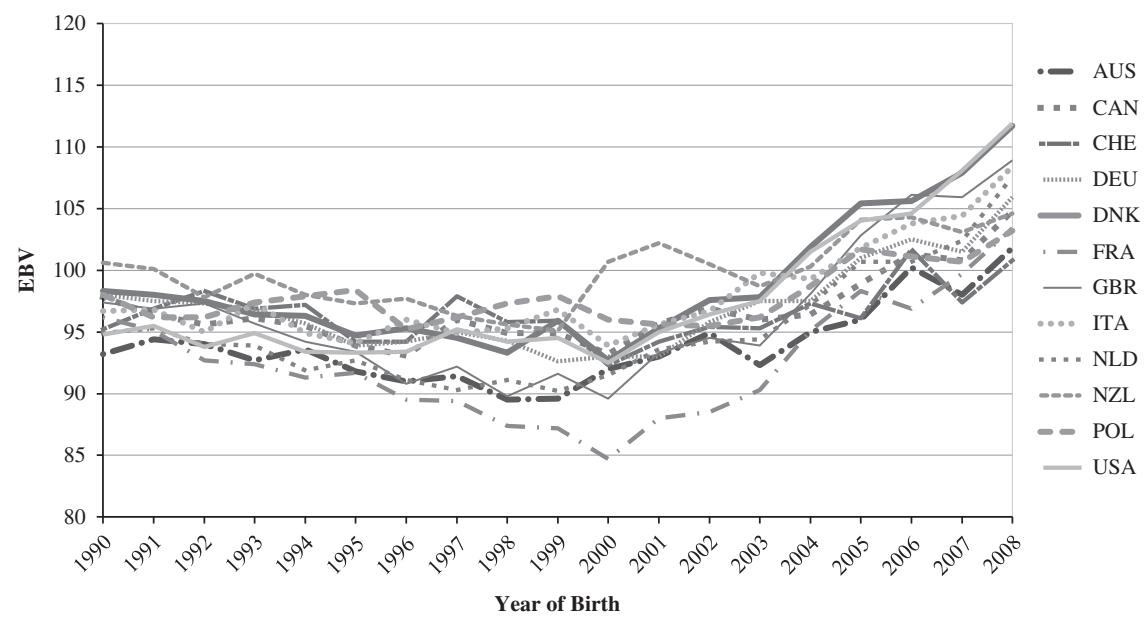

Figure 1 Average estimated breeding value for longevity by birth year and country for Holstein Friesian (Fuerst, 2014). 
strains of bacteria that can negatively impact human health. These requirements are also a part of legal regulations in the European Union (Pavon, 2013).

According to a scientific report on the effects of farming systems on dairy cow welfare and disease (EFSA-Q-2006$113,2009)$, the major diseases associated with poor welfare in dairy cows were leg disorders, mastitis and reproductive disorders. Pavon (2013) stated that genetic selection of dairy cattle over many years is considered by the European Commission to be a major factor leading to poor welfare in dairy cows, which has driven a need for welfare indicators. However, only healthy cows can perform at high levels of production for a long time, and it is important to ensure that consumers and policy makers understand this.

A key requirement for the recording of data is the motivation of the stakeholders involved. Several countries have conducted surveys with farmers to understand their needs (Steininger et al., 2012; Roessler et al., 2013; Schwarzenbacher, 2013). A consistent observation in these surveys has been that farmers place priority on the genetic progress of functional traits, aiming at robust cows that are easy to handle. Increasing milk yield is no longer ranked among the most important traits to select for, but it is quite possible that survey respondents are indicating a desire for healthy, long-lived cows that are also highly productive. Growing emphasis on functional traits indicates that they are perceived as being more important than in the past - for example, because herd sizes and labour costs are increasing but that does not necessarily mean that production is unimportant.

According to Bo (2009), a breeding goal should include the following aspects: increased income (higher production of milk/beef); reduced costs (better fertility, fewer diseases, reduced culling rates); ease of management (temperament, milking speed); and advantages regarding the sale of products (animal welfare, ethics, consumer concerns). Complex breeding goals also require information on a wide range of relevant traits that can be measured economically. In dairy cattle, these traits include efficiency, health, fertility and functional conformation. Many countries now use a diverse group of economically important traits in the TMI to rank cattle for genetic selection (Figure 2). However, recording has to have benefits beyond genetic improvement programmes, and the additional effort required for documentation must result in added value. Electronic systems that make data capture easy are a key to long-term success.

Advances in technology will have an impact on the future definition and availability of phenotypes. The growing use of SNP-based genotyping may lead to routine genomic evaluations of new traits with relatively few daughter records, particularly if producers are willing to use breeding values with lower reliabilities than they are accustomed to. Phenotypes that are expensive to measure, such as direct feed intake, may be handled by establishing small reference populations with very thorough data recording. Those data could be used to develop predictors for the broader population based on traits that are recorded in most herds (e.g. Cole et al., 2014). Recent technological developments will provide more knowledge about the biological background and genetic architecture of traits (RNAseq, genome sequencing, genomics, proteomics, metabolomics, etc.). Sequencing technologies can be used to identify causal mutations, rather than SNP in linkage disequilibrium with causal mutations, which should lead to increased accuracies of genomic prediction (Meuwissen et al., 2013). Metabolomics (the study of cellular metabolites present within an organism) and proteomics (the study of protein structure, function and patterns of expression within an organism) should lead to a better description of phenotypes, which could enhance selection opportunities.

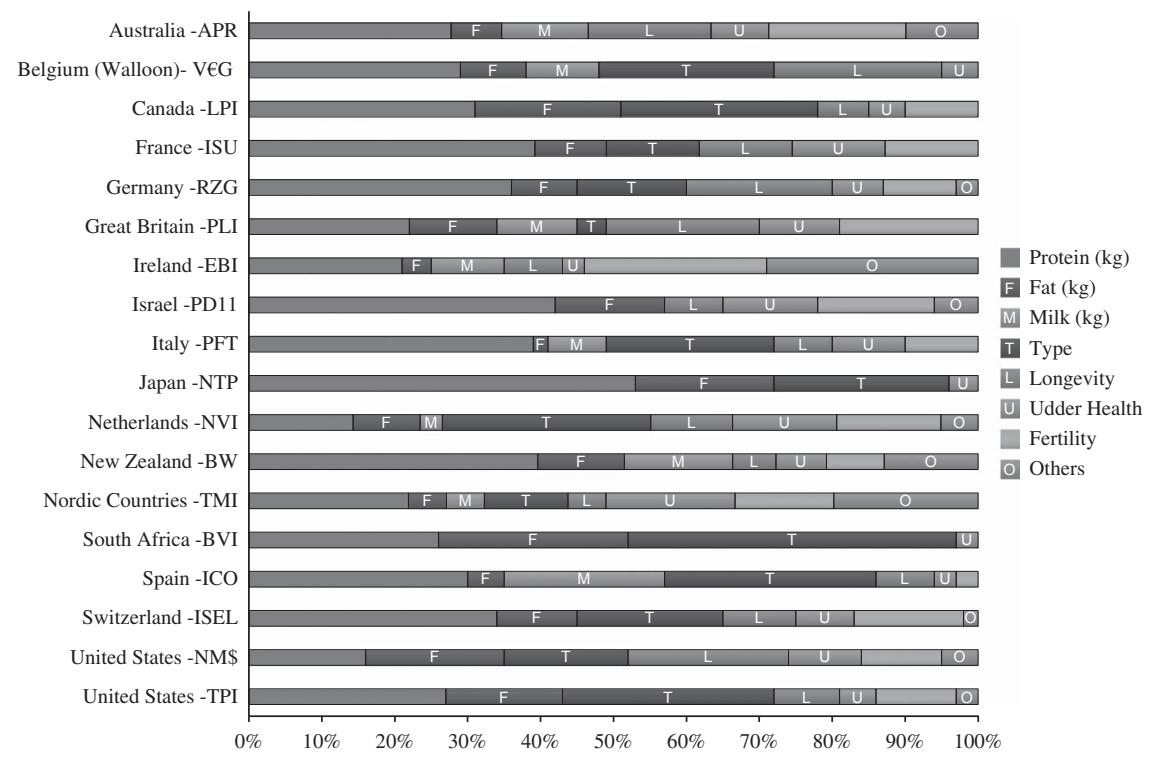

Figure 2 Traits included in the total merit indices of 17 countries. The data used to construct this figure were provided by F. Miglior of the Canadian Dairy Network. 
Egger-Danner, Cole, Pryce, Gengler, Heringstad, Bradley and Stock

\section{Novel functional traits}

\section{Direct health traits}

Several studies show that the use of direct health traits (e.g. mastitis diagnoses) is more effective than indicator traits alone in breeding programmes (Heringstad et al., 2007; Egger-Danner et al., 2012a; Parker Gaddis et al., 2014). The Nordic countries have a well-established history of health recording in dairy cows. In Norway, each case of veterinary treatment has been registered on an individual cow basis since 1975 (Heringstad and Østerås, 2013; ICAR, 2013). Similar recording systems were established in Finland, Sweden and Denmark during the 1980s. Routine genetic evaluations for direct health traits have been in place in Austria and Germany since 2010, in France since 2012 and in Canada since December 2013. Systems for recording of diagnoses are presently being established in other countries as well and will be more widely available in the near future. Some countries will use veterinary diagnoses, whereas others will focus on producer-recorded data. Developments towards integrated use of health data require standardization of diagnoses to ensure that phenotypes are comparable. Gernand et al. (2012), Govignon-Gion et al. (2012), Parker Gaddis et al. (2012) and Pryce et al. (1998) have shown that, for use in genetic evaluations, common health disorders recorded by farmers are of a similar quality as those documented by veterinarians. Combined use of health data from farmers and diagnosis documented by veterinarians may be an option to improve coverage of direct health data. In 2012, ICAR approved guidelines for Recording, Evaluation and Genetic Improvement of Health Traits (ICAR, 2012). A hierarchical system with a very comprehensive key of diagnoses (>900 entries), a reduced key of diagnoses (60 to 100 entries) and a simple key with about 10 diagnoses was described, enabling multidisciplinary use ranging from detailed information for veterinarians to simple recording of health-related observations by farmers (Table 1). International co-operation for comparability of results across countries is important.

\section{Udder health}

Mastitis is the most common trait related to udder health. In most countries, somatic cell count (SCC) is obtained from samples processed in milk-recording programmes and used as an indirect measure of mastitis; the genetic correlation between mastitis and SCC is much lower than 1 (e.g. Heringstad et al., 2006; Negussie et al., 2008). Heritability and genetic correlation estimates are presented in Table 2. Recent research has focussed on alternative definitions of SCC, such as prolonged elevated SCC (e.g. de Haas et al., 2008; Koeck et al., 2010a; Urioste et al., 2010). These novel definitions showed higher correlations with mastitis and demonstrated that temporal changes in SCC provide additional information about mastitis resistance. However, such analyses may require more frequent collection of samples than is common in many milk-recording programmes. Genetic evaluations for clinical mastitis (CM) have been computed in the Nordic countries for $>35$ years, followed by Austria, and are now common in other countries as well (see the 'Direct health traits' section). Udder health indices combining SCC and CM (and udder conformation traits) are published in some countries.

Several new methods for the detection of mastitis have been proposed. Electrical conductivity (EC) is available from some automated milking systems (AMS) and can be used as an indicator of mastitis. Collecting and implementing EC information in a breeding programme may be a challenge (Norberg, 2005), and recent literature on that topic is limited. Haeusermann and Hartung (2012) analysed data from near IR spectroscopy, real-time PCR and IR thermography to determine whether they are useful indicators of mastitis. They concluded that the development and testing of new detection methods for mastitis will require further work. Onfarm or in-line utilization of the data is not applicable for all of the techniques examined, and there is the challenge of defining a 'gold standard' for the prevention of mastitis. Recent advances in the capacity of large-scale prediction of lactoferrin (Soyeurt et al., 2012a) and mineral content indicator traits (Soyeurt et al., 2009), both known to be associated with mastitis, could also offer new opportunities to select for improved mastitis resistance (Soyeurt et al., 2012a and 2012b). Research has also been carried out on the use of pathogen-specific information in the genetic evaluation of mastitis (de Haas et al., 2002; Sorenson et al., 2009; Haugaard et al., 2012). Different bacteria may cause different immune responses, and the severity of infection and response to therapeutics can differ between pathogens. It has been shown that prevention programmes for heifer

Table 1 Example of use of the hierarchical health key published by ICAR (2012)

\begin{tabular}{llcc}
\hline \hline & Comprehensive key of diagnoses & Reduced key of diagnoses & $\begin{array}{l}\text { Simple key of } \\
\text { diagnoses }\end{array}$ \\
\hline $\begin{array}{c}\text { Number of } \\
\text { diagnosis }\end{array}$ & $>900$ & $60-100$ & $10-15$ \\
$\begin{array}{l}\text { Source } \\
\text { Recording }\end{array}$ & $\begin{array}{l}\text { Veterinarian } \\
\text { Electronic submission (veterinarian) }\end{array}$ & $\begin{array}{l}\text { Veterinarian } \\
\text { Veterinarian, performance } \\
\text { record, producer }\end{array}$ & $\begin{array}{l}\text { Producer } \\
\text { Producer }\end{array}$ \\
\hline \hline
\end{tabular}


Table 2 Heritabilities for novel traits

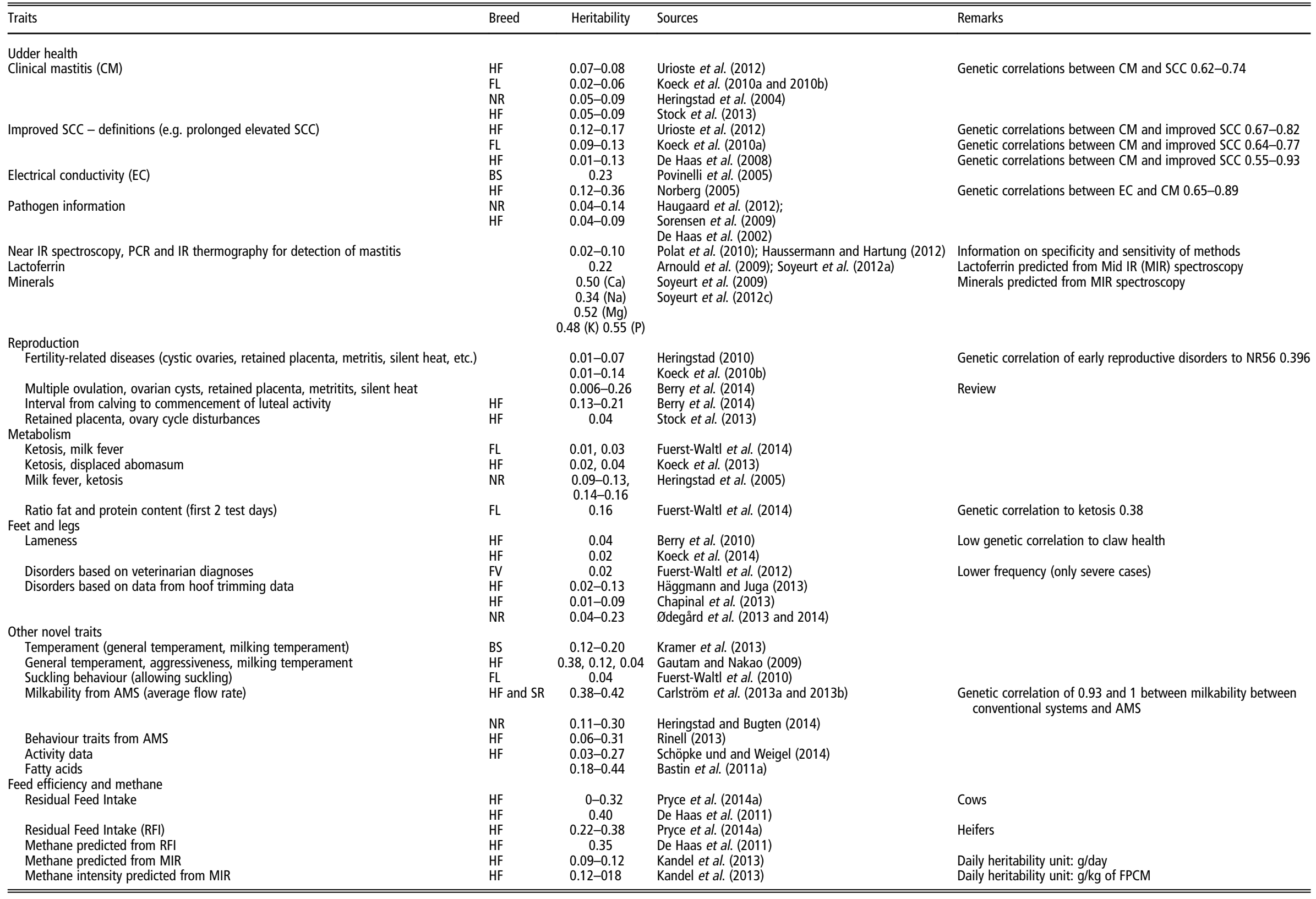


mastitis can be more efficient when information about pathogens is known (De Vliegher et al., 2012). The most significant challenge is in obtaining microbial cultures for a large number of animals because the data are expensive to collect relative to SCC or producer-reported diagnoses of CM.

\section{Reproduction}

Reproduction consists of several different traits. To establish a recording scheme for female fertility, the following data are desirable: (1) calving dates; (2) all artificial insemination dates as well as natural mating dates wherever possible; (3) information on fertility disorders; (4) pregnancy test results; (5) body condition score (BCS); and (6) hormone assays (ICAR, 2014). Routinely used fertility traits are mainly based on calving and insemination data. However, the use of fertility-related diagnoses is increasing, which envisions improved selection for reproductive health. Physical activity increases during oestrus. In addition, there are other behavioural changes, such as standing heat and mounting behaviour. These signs can be used to detect oestrus and can be used to calculate traits such as interval between calving and resumption of oestrus. It is probably unrealistic to routinely collect such data without automating heat detection. For example, pedometers and more sophisticated activity monitors are now being used routinely on many farms as part of a herd management package. The pedometer information needs to be compared with a baseline for the same cow, and algorithms have been developed to interpret the data collected. The efficiency of the oestrus detection rate has been reported to range between $50 \%$ and $100 \%$ depending on the criteria of success (At-Taras and Spahr, 2001). The 'gold standard' for oestrus detection is serum progesterone, and comparisons of pedometer - with progesterone-determined oestrus - has shown that activity monitors cannot detect silent behavioural oestrus (Lovendahl and Chagunda, 2010). However, an advantage of both progesterone- and activitydetermined oestrus is that they do not require direct observations by farm workers. Novel predictors of fertility, such as pedometers and BCS, are growing in popularity (Fogh et al., 2013). Several researchers have shown that BCS has a favourable relationship with fertility (e.g. Pryce et al., 2001; Berry et al., 2003). Research on the use of mid-infrared (MIR) predicted fatty acids as indicator traits for fertility (Bastin et al., 2012) and of MIR for pregnancy status testing is also underway (Gengler et al., 2013).

Labial position is associated with urovagina, a condition in which urine accumulates in the cranial portion of the vagina, which has harmful effects on fertility (Gautam and Nakao, 2009).

Genomics offers new possibilities for the discovery of harmful recessive effects on fertility based on the absence of homozygous haplotypes (VanRaden et al., 2011). A number of causative mutations have been identified using SNP genotypes and whole-genome sequence data (Adams et al., 2012; Fritz et al., 2013; Sonstegard et al., 2013; McClure et al., 2014), and a deletion with positive effects on milk yield and negative effects on fertility has recently been identified in Nordic Red cattle (Kadri et al., 2014). In Fleckvieh (Simmental) and Brown Swiss, deleterious mutations compromising reproductive and rearing success in cattle have been discovered (Pausch et al., 2014a and 2014b; Schwarzenbacher et al., 2012).

These methods are amenable to automation, and in the United States and several other countries the process of searching for new recessives is now a part of the genomic evaluation system.

\section{Feet and legs}

Foot and leg conditions rank among the three most frequent reasons for culling after reproduction and udder health. The conformation of feet and legs is recorded routinely by lineartype classification systems that are often part of the services offered by breed societies. Feet and leg conformation traits may be useful indicator traits for claw health. They cannot replace direct measures of claw health because their genetic correlations with claw disorders are low, but they can be used to increase the reliability of EBVs (Häggmann and Juga, 2013; Chapinal et al., 2013). Koenig et al. (2005 and 2006), Koenig and Swalve (2006) and Linde et al. (2010) showed that the efficiency of breeding for improved claw health increases considerably when claw health data are included. Routine electronic recording systems for claw health at the time of trimming exist in the Nordic countries (Johansson et al., 2011; Häggmann et al., 2013; Ødegård et al., 2013), and have been introduced in other countries as well (Kofler, 2013). Ødegård et al. (2013) showed, based on Norwegian data, that breeding for claw health is possible, and genetic evaluations based on data from claw trimming will be implemented in the breeding programme for Norwegian Red cattle in 2014.

The most frequently available information is locomotion scoring (http://www.zinpro.com/lameness/dairy/locomotionscoring). Weber et al. (2013) suggest that lameness might be a useful indicator for claw and leg health. Automated lameness detection based on activity sensors that measure lying time, number of lying bouts combined with milking and feeding data based on a cow-specific model could be a useful tool for dairy management, according to De Mol et al. (2013). Giuliana et al. (2014) showed that lameness results in behavioural changes in dairy cows in AMS. Lame cows had less feeding time and visited the robot less frequently compared with sound cows. In the Nordic countries, Austria and Southern Germany, veterinary diagnosis of feet and leg traits is recorded routinely. Several studies found that genetic evaluations based on veterinary diagnoses are valuable (e.g. Fuerst-Waltl et al., 2012). As veterinarians are typically consulted only in the most severe cases, incidence rates based on veterinary diagnoses are much lower than those based on hoof trimming information. For effective improvement of the feet and legs complex, it is important to establish systems that allow the collection of data from hoof trimmers.

\section{Metabolic status}

To date, direct traits for metabolic disorders are only rarely used in genetic evaluation. Germany and Austria publish 
EBVs for milk fever for Fleckvieh (Simmental) and Brown Swiss. The Nordic countries include this information in the EBV for general health. In herd management, milk content traits such as fat and protein percentage, fat: protein ratio, and milk urea nitrogen are used for early detection of problems associated with metabolism. Recent research has focussed on using this information for genetic improvement as well (Koeck et al., 2013; Negussie et al., 2013). One of the limitations with this approach is that if the intervals between milk recording are too long, the predictive ability is limited. Automated milk-recording systems could fill this gap by providing more frequent observations (Nicolazzi et al., 2012). Subclinical metabolic disorders like ketosis are thought to account for substantial economic losses; thus it may be important to detect subclinical signs at an early stage. These could be based on serum parameters like non-esterified fatty acids or $\beta$-hydroxybutyric acid (BHBA) concentration (Robert et al., 2012; Van der Drift et al., 2012). BHBA is the 'gold standard' of many cowside tests. The availability of such subclinical information will depend on the specificity and sensitivity of the tests as well as on ease and costs of implementation on-farm. Other potential indicator traits include MIR spectroscopy-based traits (Bastin et al., 2011b; McParland et al., 2011) or rumen activity, and BW change (Fogh et al., 2013). Melzer et al. (2013) showed that there might be potential in the identification of important metabolites that can help monitor the metabolic profile of a cow. Roche et al. (2010) have shown a relationship between BCS and metabolic disorders. The risk of metabolic disorders is higher when BCS is below 2.5 or above 3.5 .

\section{Calving traits}

Breeding values related to calving ease and stillbirth are commonly available (Interbull, 2013). Genetic evaluations usually differentiate between direct and maternal and firstand later calvings, and there is substantial variation among countries in the models used for evaluations. Although most countries use single-trait models (summarized in Cole et al., 2007, Table 1), Eaglen et al. (2012) showed that multipletrait models may be better than single-trait models, and suggest that aggregate breeding values may be an effective way of ensuring that producers place emphasis on both direct and maternal traits. Breeds differ with respect to rates of dystocia and stillbirth, and evaluations are sometimes available only for some of the breeds in a country (e.g. Cole et al., 2005; Yao et al., 2014). Health disorders related to calving difficulties are recorded in some countries.

Recent studies showed the potential of decreasing losses during the rearing period. Fuerst-Waltl and Fuerst (2010) and Fuerst-Waltl and Sorensen (2010) investigated the genetic background of postnatal mortality in calves and replacement heifers in different age groups until first calving in Danish Holsteins and Austrian Simmentals. Genetic and phenotypic variation seems to be sufficiently high to genetically improve the trait of calf and heifer mortality. Some research also has been conducted on the health traits of Holstein calves in the United States (Mousa et al., 2013), but heritability estimates were low, ranging from 0.01 to 0.06 . In a genetic analysis of respiratory disease in Norwegian Red calves, Heringstad et al. (2008) found that reasonably precise genetic evaluations of sires for calf diseases could be calculated, despite the low frequency of those diseases.

In this context, information about raising stock is important. Heifers that cycle and do not get pregnant or heifers that are inseminated but are culled before calving are of interest. Reasons also may include conformational or behavioural issues (Bethard, 2008). The trait longevity is included in the total merit index in most of the countries. However, losses during rearing are generally not considered, or are included in a very simple manner. Mortality in dairy cattle is relevant not only with regard to economic losses but also with regard to animal health and welfare. McCorquodale et al. (2013) showed the potential of using calfhood diseases and survival in future dairy cattle breeding programmes.

\section{Feed efficiency}

An expected increase in prices for concentrates and energy will increase the focus on feed efficiency. Efficiency can be defined as output per input unit at the farm level, as well as for individual animals. Residual feed intake (RFI), also known as net feed efficiency, is growing in popularity as a measure of feed efficiency. RFI is generally calculated as the difference between actual and predicted dry matter intake (DMI). Efficient animals have lower DMI at the same level of milk production and the same weight. The greatest obstacle in the widespread use of feed intake and feed efficiency measures in breeding objectives is the availability of large quantities of feed intake data on individual animals (Berry and Crowley, 2013). There are two promising options for enabling selection for RFI: (1) predictor traits (Fogh et al., 2013) and (2) genomic prediction (Pryce and Berry, 2014; Pryce et al., 2014a and 2014b).

Rumen activity might be a future indicator trait for feed efficiency. Other measures in feed, faeces and urine samples are being developed - for example, metagenomic predictions using the rumen microbiome (symbiotic microorganisms) of enteric methane in cattle and body mass index in humans are showing promise (Ross et al., 2013) and could possibly also be used for predicting RFI (De Marchi et al., 2014). In a recent review by Pryce et al. (2014a), which included seven studies of beef and dairy cattle, the accuracy of genomic predictions of RFI, energy balance and DMI ranged between 0.20 and 0.43 . In theory, a genomic reference population can be assembled using a sub-population of animals with genotypes and phenotypes used to generate a genomic prediction equation (Berry et al., 2014; Pryce et al., 2014a and 2014b). The genomic prediction equation can then be applied to the rest of the population. However, farmers are unlikely to accept accuracies in the range currently estimated $(<16 \%)$. This means that much larger populations need to be assembled. An international collaboration is endeavouring to build a data set of $>6000$ individuals with genotypes and phenotypes (from nine contributing partners) (Berry et al., 2014; Pryce and Berry, 2014; Pryce et al., 2014a and 2014b). 
Selection for $\mathrm{RFI}$, or $\mathrm{RFI}$, has been reported to lead to reductions in methane emissions of $\sim 13.45 \mathrm{~g} \mathrm{CH}_{4} / \mathrm{kg} \mathrm{RFI}$ (Hegarty et al., 2007) and $18.2 \mathrm{~g} \mathrm{CH} 4 / \mathrm{kg} \mathrm{RFI}$ (Nkrumah et al., 2006). A similar potential for abatement has been observed in Holstein dairy cattle, $17.5 \mathrm{~g} \mathrm{CH}_{4} / \mathrm{kg} \mathrm{RFI}$ (Pryce et al., unpublished data). Reducing RFI by $1 \mathrm{~kg}$ could lead to between $4 \%$ and $8 \%$ reduction in methane emissions. If RFI was to be included in the Australian national breeding objective, the Australian Profit Ranking, then it is predicted that RFI would reduce by $1.76 \mathrm{~kg} / \mathrm{cow}$ per year (GonzalezRecio et al., 2014a). Direct measurement of methane is expensive and is unlikely to be available in sufficient numbers for breeding in the near future, unless novel ways of measuring methane on large numbers of animals that are currently being tested prove to be successful. Chagunda et al. (2009) reported that a laser methane detector can be used to accurately estimate enteric methane output in dairy cows without affecting their normal activity. Dehareng et al. (2012) and McParland et al. (2014) reported the potential capacity to provide MIR spectra-based methane indicators. Such systems may be an attractive way to collect many phenotypes if they are cost-effective and durable.

\section{Other novel traits}

\section{Behavioural traits}

Other traits, such as temperament, are of growing interest because farmers want cows that are easy to handle. From the aspect of animal welfare, these traits are gaining interest as well. So far, little information about heritabilities of behavioural traits is available, but commercial dairymen cull animals because of poor temperament (Berry et al., 2005). Temperament or behaviour is often subjectively scored. According to Kramer et al. (2013), heritabilities based on phenotypes scored by independent people were lower than when scored by farmers $(0.12$ v. 0.20). Kramer et al. (2013) analysed traits including general temperament, milking temperament, aggressiveness, rank order in herd, milking speed and position of labia for Brown Swiss. General temperament was scored by farmers using a 5 -point scale $(1=$ very nervous and $5=$ very calm) as described by Juga (1996). The heritability for general temperament was 0.38 , that for aggressiveness was 0.12 and that for milking temperament was 0.04 .

\section{Traits out of data from AMS}

AMS offer the possibility to record traits related to workability, which are described by Rinell (2013). Temperament or behaviour, ease of handling and milkability are examples of traits that could be derived from measures routinely recorded in AMS. A measure of temperament from the AMS system could be teat cup attachment failures. Rinell (2013) estimated genetic correlations of $r=-0.38$ and $r=-0.50$ between two teat cup attachment failure traits and temperament. Different approaches concerning milking speed are used. Data from AMS offer new possibilities to record such traits automatically (Byskov et al., 2012; Carlström et al., 2013a and 2013b). Carlström et al. (2013b) compared milkability from conventional milking parlours with AMS systems. They showed genetic correlations of 0.93 and 1.00 between the two systems and concluded that the inclusion of only one trait in breeding programmes is sufficient. Lovendahl et al. (2012) also discuss milking efficiency, in addition to milking speed. Milking efficiency describes the yield of ECM per minute in the milking box and is of interest for automated milking. This includes time for entry, cleaning, attachment, milking, exit and unit cleaning.

\section{Adaptation to climate change}

Exposure of animals to extreme weather conditions can be used as proxy for future climate change. Such exposure will trigger autonomous adaptations by the animals, but these adaptations are not perfect and therefore residual impacts or vulnerabilities will remain (Smit et al., 1999). By quantifying these non-adaptations, novel traits can be defined to assess the degree of resilience of an animal to climate change. Resilience can be defined in many ways, the simplest of which may be the individual response of an animal to a stressor variable linked to the weather. A commonly used stressor variable is the temperature heat index, initially developed by Thom (1959) as a heat index for human comfort, and is commonly used as indicator of heat stress. Reported research in this field addressed individual responses in both production and functional traits and reported clear trait differences, fertility and intake being often considered the most strongly affected (e.g. Kadzere et al., 2002; De Rensis and Scaramuzzi, 2003; West, 2003). Recent research also reported responses in some novel traits having a direct biological meaning. Gengler (2014) reported, in this context, the reaction of MIR-predicted fatty acid C18:1-cis9 content in milk to heat stress. Several authors have shown that this trait reflects very well the equilibrium between mobilization and intake - heat-stressed animals eating less and mobilizing more (e.g. De Rensis and Scaramuzzi, 2003). This element is of large importance when considering both adaptation to and mitigation of climate change in climate conscious breeding objectives. More detailed physiologically based adaptation traits such as heat shock proteins have been proposed (Lewis et al., 1999), but large-scale phenotyping is obviously more difficult to organize and these traits are therefore less useful for practical breeding.

Currently, despite promising research results, in cattle, no large-scale breeding programme directly includes adaptation traits. However, current breeding objectives are indirectly affecting adaptation given the unfavourable correlations between resilience and production traits (e.g. West, 2003). Although profound scientific knowledge about the detailed relationships of resilience traits with other traits might still be missing, it can be hypothesized that more resilient animals are also more robust animals (i.e. more fertile) in general.

\section{Sucking traits}

Another trait of interest is suckling behaviour. Cross-suckling and inter-suckling are considered abnormal behaviours in 
cattle and constitute a common problem in dairy farming (Fuerst-Waltl et al., 2010). De Passillé (2001) noted that deprivation of the opportunity to suck may interfere with digestive processes and used an artificial feeding system to examine the effects of milk flow rate on calf behaviour. In a review of dairy cow behaviour, Von Keyserlingk et al. (2009) concluded that calf feeding systems that allow the expression of normal behaviours, such as sucking on a teat, are best for the animals. Studies of oral behaviours in calves are typically based on direct observations, and the general consistency of independent studies suggests that the methodology used to record those behaviours is adequately standardized (e.g. Margerison et al., 2003).

\section{Milk fatty acids}

Fine milk composition traits, and in particular fatty acid profiles, can be considered another group of traits of interest (Gengler and Soyeurt, 2010). The importance of this type of traits is double: first, directly as indicators of milk quality (Bauman et al., 2006) and, second, also as indicators of the physiological and health status of the animals (e.g. Bastin et al., 2011b). Some studies established a link between milk composition and the environmental footprint of cows for nitrogen (Jonker et al., 1998) and for methane (Mohammed et al., 2011), these emissions being linked to fatty acid profiles. Unfortunately, measuring fine milk composition, and especially fatty acid composition, is not feasible on a large scale in an economical fashion as reference chemical analyses are very expensive and time-consuming. Recently, through the use of MIR spectroscopy, the prediction of most major fatty acids has become feasible on a large scale (Soyeurt et al., 2011), creating new opportunities for the recording and use of novel fine milk composition traits, in particular fatty acids.

\section{Milk coagulation properties}

Several physical characteristics of milk that are of importance in cheese manufacture have been described in the literature, including rennet coagulation time, curd firmness $30 \mathrm{~min}$ after rennet addition, and curd-firming time (Bittante et al., 2012). These traits are largely genetically independent of milk yield (Ikonen et al., 2004), and there is interest in improving those traits in many breeds (Ikonen et al., 1999; Cecchinato et al., 2011). One limiting factor in providing such evaluations is the time and expense involved in collecting the phenotypes, but recent research suggests that MIR spectroscopy may provide reasonable predictors that can be measured on many samples affordably (Cecchinato et al., 2009).

\section{Beef traits}

Carcass traits are routinely recorded at slaughter houses and are available for genetic evaluation. This includes traits like dressing percentage, trading score and information about net daily gain. According to a survey carried out by Gene2Farm, tenderness is another trait that is more widely recorded for beef breeds. The availability of beef quality traits is still limited and under research (e.g. Gene2Farm). As the collection of beef quality traits is very expensive, genomics offers the chance to set up registration of these traits for a limited number of genotyped animals. A detailed review of this topic is outside the scope of this study.

\section{Recording systems and sources of data for novel traits}

For accurate breeding values there are two major possibilities: either cost-effective phenotypes are required on a large scale or investment must be made in the genotyping and collection of high-cost phenotypes for a limited number of females. Owing to advances in technologies, new traits based on lab data or automation are offering new possibilities. Many precision dairy farming technologies, including daily milk yield recording, milk component monitoring (e.g. fat, protein and SCC), pedometers, automatic temperature recording devices, milk conductivity indicators, automatic oestrus detection monitors and daily BW measurements, are already being utilized by dairy producers (Bewley, 2010). To invest in this equipment is expensive and will only pay for large farms. According to the review by Rutten et al. (2013), sensor systems for mastitis and reproduction are brought to a high level of development, but still need to improve detection performance.

Laboratory data include indirect health data with a spectrum of traits according to sampling protocols and testing requests (e.g. microbiological testing, metabolite analyses, hormone tests, virus/bacteria DNA, IR-based measurements) (Soyeurt et al., 2009). The advantage of lab data is that, in general, they are automated or semi-automated recording systems that produce objective measurements, and many data can be obtained at low cost. The disadvantage might be that, for example, for bacteriological findings or hormonal assays - data might be only from preselected animals.

To use synergies and enlarge the range of possible phenotypes for genetic collaboration with other organizations and institutions is an option (Figure 3). Data security issues have to be considered, and standardized protocols for ensuring security are necessary. Slaughter houses, dairy plants, health organizations and other entities are routinely recording data for their own purposes. The monitoring of welfare is gaining increasing importance. The central role of dairy cattle health in the context of animal welfare and consumer protection implies that farmers and veterinarians are obligated to maintain high-quality records, emphasizing the particular sensitivity of health data. The legal requirement to monitor the development of different indicator traits offers the possibility of synergies for recording of traits. One example is direct health data, which are partly recorded based on legal documentation requirements (Stege et al., 2003; Østerås et al., 2007; Egger-Danner et al., 2012b).

\section{Genotyping females in research herds}

As several novel traits currently under investigation are expensive to record, using research herds for phenotyping in combination with genomics are an attractive source of data, as are herds that engage in intensive data collection. These farms are of particular interest for feed efficiency, methane 
Egger-Danner, Cole, Pryce, Gengler, Heringstad, Bradley and Stock

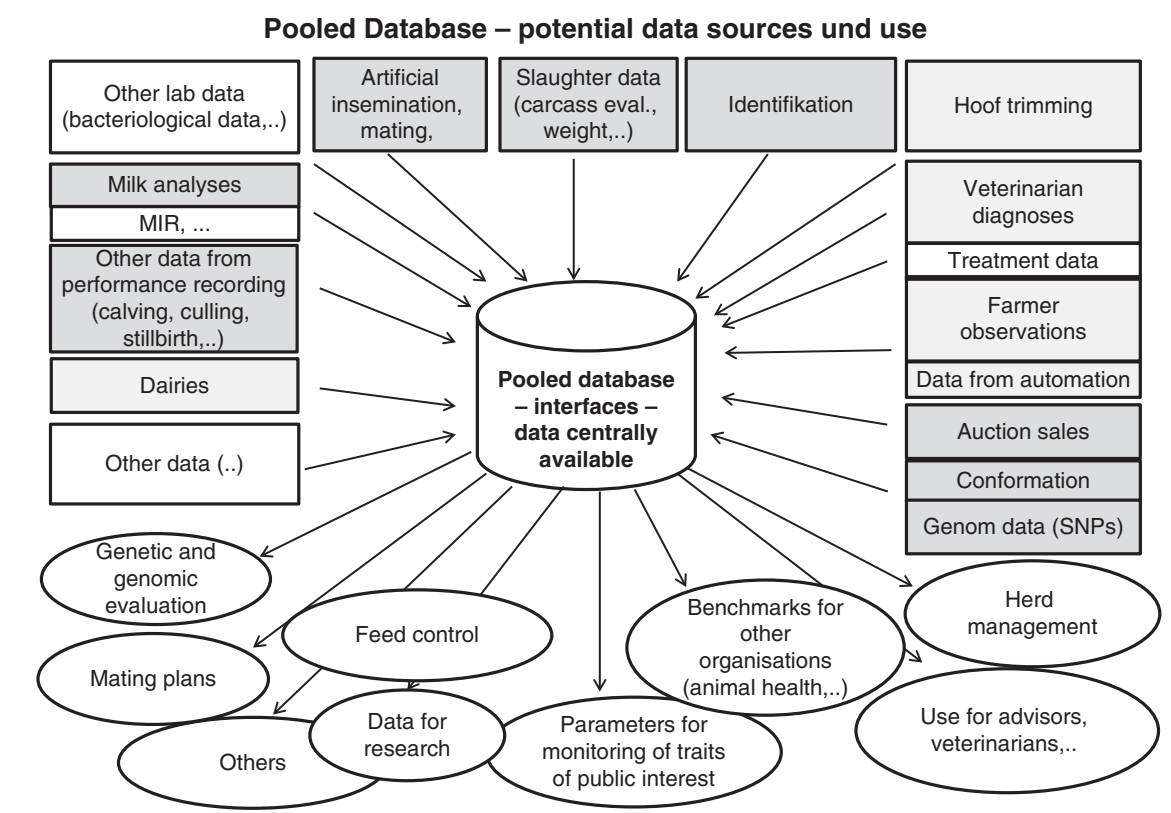

Figure 3 Pooled database with potential data sources and examples of use of data. grey $=$ commonly used data; light grey = partly used data; white $=$ data sources of interest.

emission and high-cost health traits. As several thousand phenotypes are required to accurately determine the characteristics of traits in terms of heritability and correlations to other traits of interest in the breeding goal (Calus et al., 2013a), there is a clear need to invest in phenotyping of many animals for the new traits, as well as possible indicator traits (Gonzalez-Recio et al., 2014b).

In breeding programmes worldwide, more and more young bulls with genomic expected breeding values (GEBVs) are used. The reliability of the GEBVs depends to a very high extent on the size of the reference population. To achieve genetic response for the novel trait, the reliability of the trait is crucial. The limitation for novel traits where phenotyping has only recently started is that it will be very difficult or impossible to establish a large reference population based on bulls, as the number of bulls used within breeding programmes has been reduced because of genomic selection. Methods to increase the accuracy of genomic predictions are as follows: enlarging the reference population, using chips of higher density, imputing from lower densities to higher densities and the inclusion of ungenotyped cows in the reference population (Pszcola et al., 2013).

Enlarging the reference population by adding females is also a possibility. Simulation studies (e.g. Buch, 2011; Pszcola et al., 2013; Gonzalez-Recio et al., 2014b) show that for novel traits and limited resources it is more effective to genotype females than only males. The impact of the cow reference population also depends on the sampling strategy. Including only elite dams will only result in minor increases of reliabilities and may lead to biased estimates. Exploring the variation of the trait by sampling extreme cows (top tails and bottom tails of distribution) will increase the benefit (Jimenez-Montero et al., 2012). However, it is desirable to either randomly select cows or select those that will contribute the most data, which is the strategy being applied in the Australian genomic information nucleus known as Ginfo (Australia's genomic information nucleus). Traits with medium to high heritability gain more from genotyping cows than direct health traits with low heritability (Egger-Danner et al., 2014). Bolignon et al. (2012) showed that reference population animals with extreme yield deviations are the most informative for genomic selection. De Haas et al. (2012) have shown that it is possible to increase the number of genotypes and phenotypes by merging data from various research herds worldwide. Validation of equations in completely independent populations showed promising results (Pryce et al., 2014b). Different studies stress the optimum design of female reference populations to use resources efficiently (Buch, 2011; Pszczola et al., 2012; Thomasen et al., 2014). It is important that the variance of the trait can be explored and that the relationship within the reference population is low but closely related to the evaluated population. Therefore, it is important to update the reference population continuously.

Experiences from the United States showed that there is some gain from the inclusion of cows in the predictor population (Wiggans et al., 2011), but adjustments to their records may be needed to avoid potential biases (Dassonneville et al., 2012; Wiggans et al., 2012). The use of cows in predictor populations for novel traits that lack a large group of bulls with high-reliability evaluations will be necessary. Table 3 gives an overview of $\mathrm{gEBV}$ reliabilities for novel traits. So far, experience is limited with real data. However, it is unclear whether or when low-reliability cow data should be removed from the predictor population as the reliability of sire EBV increases.

Cost efficiency is an important criterion for the success and sustainability of breeding programmes. Therefore, it might 
Table 3 Reliabilities of genomic EBVs for novel traits

\begin{tabular}{|c|c|c|c|c|c|}
\hline Traits & Novel traits & $\begin{array}{l}\text { Size of calibration } \\
\text { group }\end{array}$ & $\begin{array}{l}\text { Reliability/ } \\
\text { accuracy* }\end{array}$ & Sources & Remarks \\
\hline \multirow[t]{2}{*}{ Udder health } & $\mathrm{CM}$ & 2563 bulls & 0.26 & $\begin{array}{l}\text { Heringstad et al. } \\
\quad(2011)\end{array}$ & \\
\hline & & $\begin{array}{l}7800 \\
\text { bulls }+10000 \\
\text { cows }\end{array}$ & $0.17 / 0.23$ & $\begin{array}{l}\text { NAV Routine } \\
\text { Evaluation (2014) }\end{array}$ & $\begin{array}{l}\text { Increase related to pedigree index (RDC) (bulls/ } \\
\text { bulls + cows in reference) }\end{array}$ \\
\hline Reproduction & $\begin{array}{l}\text { Fertility-related } \\
\text { disorders }\end{array}$ & 3363 bulls & $0.17-0.65^{*}$ & Haugaard et al. (2014) & Correlation GEBV and EBV \\
\hline \multirow[t]{2}{*}{ Feet and legs } & Claw health & 967 bulls & $0.29-0.35^{*}$ & Ødegård et al. (2014) & Correlation GEBV and DYD \\
\hline & & $\begin{array}{l}7800 \\
\text { bulls }+10000 \\
\text { cows }\end{array}$ & $0.24 / 0.33$ & $\begin{array}{l}\text { NAV Routine } \\
\text { Evaluation (2014) }\end{array}$ & $\begin{array}{l}\text { Increase related to pedigree index (RDC) (bulls/ } \\
\text { bulls + cows in reference) }\end{array}$ \\
\hline \multirow{3}{*}{$\begin{array}{l}\text { Feed } \\
\text { efficiency }\end{array}$} & RFI & Various & $0.40-0.43^{*}$ & Pryce et al. (2014a) & \\
\hline & Energy balance & & $0.29^{*}$ & Pryce et al. (2014a) & \\
\hline & Dry matter intake & & $0.20-0.35^{*}$ & Pryce et al. (2014a) & \\
\hline $\begin{array}{l}\text { Other } \\
\text { diseases }\end{array}$ & Other diseases & $\begin{array}{l}7800 \\
\text { bulls }+10000 \\
\text { cows }\end{array}$ & $0.17 / 0.17$ & $\begin{array}{l}\text { NAV Routine } \\
\text { Evaluation (2014) }\end{array}$ & $\begin{array}{l}\text { Increase related to pedigree index (RDC) (bulls/ } \\
\text { bulls + cows in reference) }\end{array}$ \\
\hline
\end{tabular}

GEVB = genomic estimated breeding value; $\mathrm{RDC}=$ red dairy cattle; $\mathrm{DYD}=$ daugher yield deviation; $\mathrm{RFI}=$ residual feed intake; ${ }^{*}=$ accuracy.

be too expensive to continuously record data extensively on research herds. Indictor traits with known genetic correlation to the direct trait of interest may be used instead. According to Pszcola et al. (2013), easily recorded predictor traits could be used to increase the reliability of scarcely recorded traits for example, fat- and protein-corrected milk yield and live weight for DMI - and the bias of genomic breeding values of scarcely recorded traits could be reduced. As described under the various trait complexes, this approach could be applicable also for metabolism, feet and legs and other traits (Axelsson et al., 2013). Genomic selection programmes for indicator traits also benefit from the inclusion of cows in the reference population (Calus et al., 2013a and 2013b).

\section{Challenges}

\section{Predictive biology}

Biomarkers, such as metabolites or milk components, may be rich sources of information about novel phenotypes (Gengler et al., 2013). Standard analyses undertaken by milkrecording laboratories, such as by MIR spectroscopy, generate spectral data that reflect many characteristics of milk. Research is currently underway to investigate the use of this data for prediction of indicator traits (RobustMilk, OptiMIR, PhenoFinlait, GplusE, etc.). The main challenge posed by these data is the lack of reference data for the detection of disease, such as mastitis. A reliable pool of 'healthy' and 'sick' animals is required. For traits with low heritability and limited reliability and repeatability, this is even more difficult. The reference data set has to account for different production circumstances. There is the need for comparability of spectra from different instrument manufacturers (Foss, Bentley, Delta, etc.), models within brands, and stability over time. The repeatability of results across different breeds and production environments, as well as logistical challenges related to data collection and transfer, must be considered. This includes extracting data from spectrometers and storing of MIR spectra, standardizing spectra, complex computation of indicators and finally the implementation into routine milk-recording work flow (Soyeurt et al., 2012b and 2012c; Gengler et al., 2013).

Predictive biology is also a topic for other sensor techniques. According to a review by Rutten et al. (2013), research is still needed. In the future, genomic data could be integrated to improve the prediction. Different environmental effects, such as feeding and management, can influence the prediction equations. Therefore, there is also a need for calibration across breeds and countries (De Marchi et al., 2014). Prediction equations are derived using reliable phenotypes from a large sample of animals, with the ultimate goal of predicting phenotypes directly from the MIR spectra. In Figure 4, the system of prediction is described. The prediction equation is derived based on reliable phenotypes for novel traits (e.g. mastitis) from a larger sample of animals. The ultimate goal is to predict phenotypes directly from, for example, MIR spectra. Advances could be that these equations are improved by taking the genomic information into account.

\section{Standardization and integration of relevant data sources}

There are many mechanical and electronic systems on dairies that can be used as sources of new phenotypes (Figure 5). Automatic milking and feeding systems, for example, routinely generate many observations. Among them, which data are actually stored is again different. There is a need for harmonization in trait definitions across systems and devices. An additional challenge is the availability of data. Many systems use process computers that do not communicate with external databases. This results in data that are 'stranded' in different 
Egger-Danner, Cole, Pryce, Gengler, Heringstad, Bradley and Stock

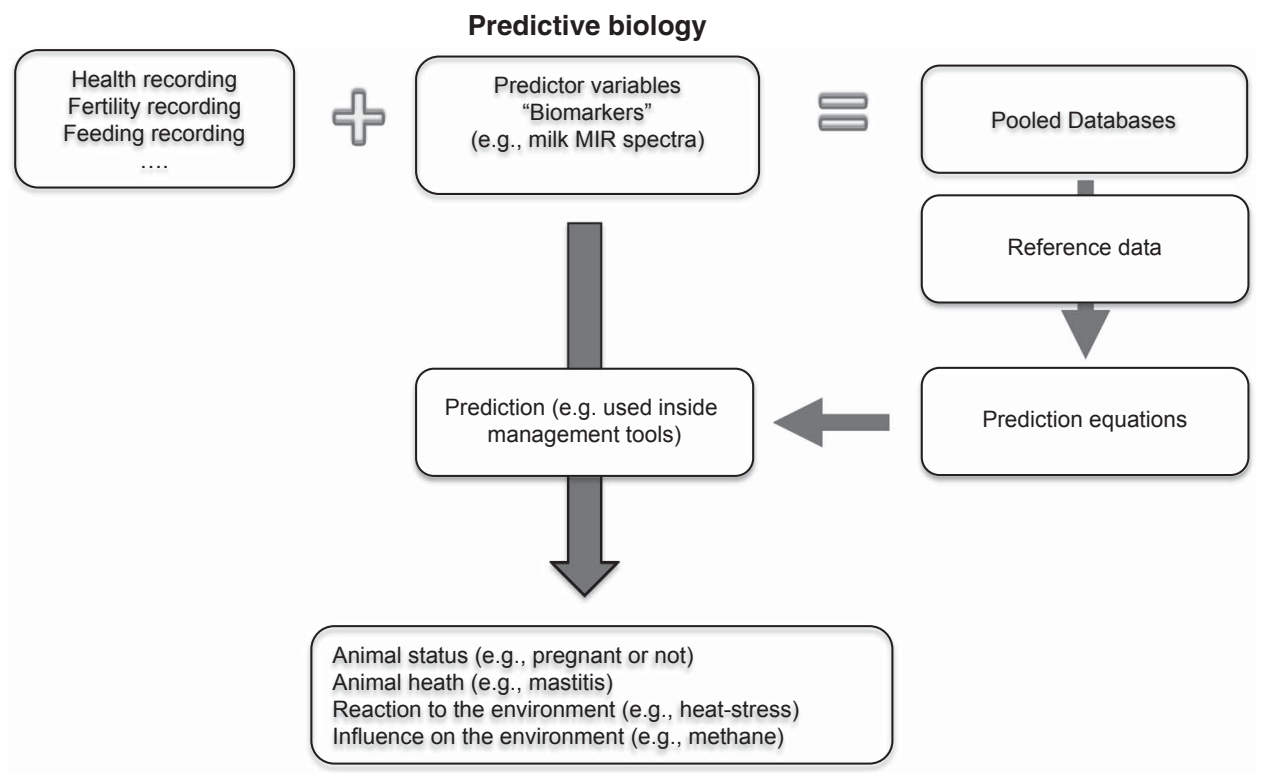

Figure 4 Overview about the system of predictive biology to determine traits based on prediction equations.

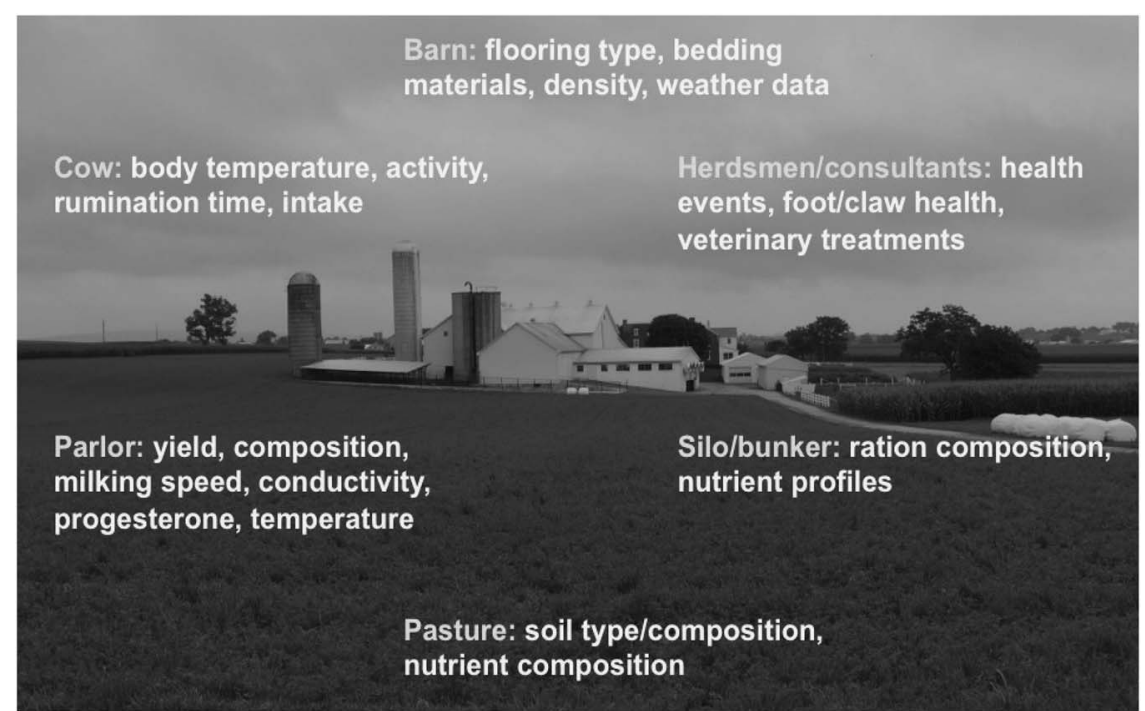

Figure 5 Sources of on-farm information that can be used to collect health and fitness phenotypes (source: http://commons.wikimedia.org/wiki/File: Amish_dairy_farm_3.jpg).

systems that cannot easily be integrated into a single database for analysis. When such data are available in a central database, they can also be used for benchmarking, which offers an opportunity to compare performance both between and within farms over time. A single parameter does not provide an appropriate benchmark, and indices based on a basket of parameters may provide a better marker of overall performance (Bradley et al., 2013). Benchmarks also provide farmers with rapid feedback about the effect of management changes on farm performance, and may encourage ongoing participation in data collection programmes.

\section{Simplicity and ease-of-use for farmers}

The future availability of phenotypic data will depend heavily on the motivation of the farmers. It is expected that the traits and data available will further increase. The challenge is to present those data in a way that does not overwhelm farmers when providing useful tools. Easy handling and simple access to data is essential because time is a limiting factor on most farms.

\section{Conclusions}

Conditions of production, as well as consumer demands, will have an impact on the future availability of phenotypes. Traits connected with animal health, animal welfare, food safety and efficiency will become more important. Advances in technology will enable more precise trait definitions, with phenotypes closer to the genotype. Technological advances will permit the closer integration of existing data sources. 
New technologies are expected to provide better indicator traits for fertility, mastitis, metabolism and energy efficiency. There are still challenges to solve before some technologies can be widely applied on a routine basis, including the predictive biology of indicator traits, the harmonization of data from automated systems, the motivation of farmers to record high-quality phenotypes and the genomic gap for novel traits. To overcome the phenomic gap between traditional traits and novel traits, expanded genotyping of cows should be considered. International co-operation will ensure that trait definitions are consistent across countries and will support the research necessary to deliver new management and selection tools to farmers.

\section{Acknowledgements}

This review is based on an invited presentation at the 64th Annual Meeting of the European Association for Animal Production held in Nantes, France, August 2013. Excellent cooperation within ICAR Working Group Functional Traits. Federal Ministry of Agriculture, Forestry, Environment and Water Management (BMLFUW) in Austria and the Federation of Austrian Cattle Breeders for the support within the projects 'Efficient cow' and 'OptiGene'. Gene2Farm (EU-FP7-KBBE-2011-5-PNr.: 289592) for provision of information. J. B. Cole was supported by appropriated project 1265-31000-096-00, 'Improving Genetic Predictions in Dairy Animals Using Phenotypic and Genomic Information', of the Agricultural Research Service of the United States Department of Agriculture. N. Gengler was supported by the INTERREG IVB NWE Project 190G OptiMIR: new tools for a more sustainable dairy sector and the Ministry of Agriculture of the Walloon Region of Belgium (Service Public de Wallonie, Direction générale opérationnelle 'Agriculture, Ressources naturelles et Environnement' - DGARNE) for the support within the project 'MethaMilk' (D31-1248 and D311304). J. E. Pryce acknowledges financial support from the Department of Environment and Primary Industries (Melbourne, Australia).

\section{References}

Adams HA, Sonstegard T, VanRaden PM, Null DJ, Van Tassell CP and Lewin H 2012. Identification of a nonsense mutation in APAF1 that is causal for a decrease in reproductive efficiency in dairy cattle. Proceedings of the Plant \& Animal Genome XX Conference, 14-18 January 2014, San Diego, CA, USA, abstract. P0555.

Arnould VMR, Soyeurt H, Gengler N, Colinet FG, Georges MV, Bertozzi G, Portelle D and Renaville R 2009. Genetic analysis of lactoferrin content in bovine milk. Journal of Dairy Science 92, 2151-2158.

At-Taras EE and Spahr SL 2001. Detection and characterization of estrus in dairy cattle with an electronic heatmount detector and an electronic activity tag. Journal of Dairy Science 84, 792-798.

Axelsson H, Fikse WF, Kargo M, Sorensen AC, Johansson K and Rydhmer L 2013. Genomic selection using indicator traits to reduce the environmental impact of milk production. Journal of Dairy Science 96, 5306-5314.

Bastin C, Gengler N and Soyeurt H 2011a. Phenotypic and genetic variability of production traits and milk fatty acid contents across days in milk for Walloon Holstein first-parity cows. Journal of Dairy Science 94, 4152-4163.
Bastin C, Soyeurt H, Vanderick S and Gengler N 2011b. Genetic relationship between milk fatty acids and fertility of dairy cows. Interbull Bulletin 44, 195-199.

Bastin C, Berry DP, Soyeurt H and Gengler N 2012. Genetic correlations of days open with production traits and contents in milk of major fatty acids predicted by mid-infrared spectrometry. Journal of Dairy Science 95, 6113-6121.

Bauman DE, Mather IH, Wall RJ and Lock AL 2006. Major advances associated with the biosynthesis of milk. Journal of Dairy Science 89, 1235-1243.

Berry DP and Crowley JJ 2013. Cell biology symposium: genetics of feed efficiency in dairy and beef cattle. Journal of Animal Science 91, 1594-1613.

Berry DP, Wall E and Pryce JE 2014. Genetics and genomics of reproductive performance in dairy and breed cattle. Animal 8 (suppl. 1), 105-121.

Berry DP, Harris BL, Winkelman AM and Montgomerie W 2005. Phenotypic associations between traits other than production and longevity in New Zealand dairy cattle. Journal of Dairy Science 88, 2962-2974.

Berry DP, Buckley F, Dillon P, Evans RD, Rath M and Veerkamp RF 2003. Genetic relationships among body condition score, body weight, milk yield, and fertility in dairy cows. Journal of Dairy Science 88, 2193-2204.

Bethard G 2008. Quantifying a heifer culling decision. Dairy Calf and Heifer Association Conference, 1-3 April. Rochester, MN, USA. Retrieved 20 March 2014, from http://sroc.cfans.umn.edu/prod/groups/cfans/@pub/@cfans/@sroc/ @outreach/documents/article/cfans_article_117790.pdf

Bewley J 2010. Precision dairy farming: advanced analysis solutions for future profitability. Retrieved 28 March 2014, from http://www.precisiondairy2010. com/proceedings/s1bewley.pdf

Bittante G, Penasa M and Cecchinato A 2012. Invited review: genetics and modeling of milk coagulation properties. Journal of Dairy Science 95, 6843-6870.

Bo N 2009. Practical cattle breeding in the future - commercialised or co-operative, across borderlines between countries and organisations. Retrieved 28 March 2014, from https://journal.interbull.org/index.php/ib/article/viewFile/ $1122 / 1113$

Bolignon AA, Long N, Albuquerque LG, Weigel KA, Gianola D and Rosa GJ 2012. Comparison of selective genotyping strategies for prediction of breeding values in a population undergoing selection. Journal of Animal Science 90, 4716-4722.

Bradley AJ, Breen JA, Hudson CD and Green MJ 2013. Benchmarking for health from the perspective of consultants. Challenges and benefits of health data recording in the context of food chain quality, management and breeding. Proceedings of the ICAR Health Data Conference, 30-31 May 2013, Aarhus, Denmark, ICAR Technical Series no. 17, 159-166.

Buch LH 2011. Genetic improvement of functional traits in dairy cattle breeding schemes with genomic selection. PhD, Aarhus University, Aarhus, Denmark.

Byskov K, Buch LH and Aamand GP 2012. Possibilities of implementing measures from automatic milking systems in routine evaluations of udder conformation and milking speed. Interbull Bulletin 46, 28-32.

Calus MPL, de Haas Y, Pszczola M and Veerkamp RF 2013a. Predicted accuracy of and response to genomic selection for new traits in dairy cattle. Animal 7, 183-191.

Calus MPL, Bijma P, van Arendonk J and Veerkamp RF 2013b. Economics of using genomic selection at the farm level. Book of Abstracts of the 64th Annual Meeting of the European Association for Animal Science. 26 August 2013, Nantes, France, 184pp.

Carlström C, Petterson G, Johansson K, Strandberg E, Stålhammar H and Philipsson J 2013a. Feasibility of using automatic milking system data from commercial herds for genetic analysis of milkability. Journal of Dairy Science 96, 5324-5332.

Carlström C, Strandberg E, Johansson K, Pettersson G, Stålhammar $H$ and Philipsson J 2013b. Genetic evaluation of in-line recorded milkability from milking parlors and automatic milking systems. Journal of Dairy Science 97, 497-506.

Cecchinato A, De Marchi M, Gallo L, Bittante G and Carnier P 2009. Mid-infrared spectroscopy predictions as indicator traits in breeding programs for enhanced coagulation properties of milk. Journal of Dairy Science 92, 5304-5313.

Cecchinato A, Penasa M, De Marchi M, Gallo L, Bittante G and Carnier P 2011. Genetic parameters of coagulation properties, milk yield, quality, and acidity estimated using coagulating and noncoagulating milk information in Brown Swiss and Holstein-Friesian cows. Journal of Dairy Science 94, 4205-4213.

Chagunda MGG, Ross D and Roberts DJ 2009. On the use of a laser methane detector in dairy cows. Computers and Electronics in Agriculture 68, 157-160. 
Chapinal N, Koeck A, Sewalem A, Kelton DF, Mason S, Cramer G and Miglior F 2013. Genetic parameters for hoof lesions and their relationship with feet and leg traits in Canadian Holstein cows. Journal of Dairy Science 96, 2596-2604.

Cole JB, Wiggans GR and VanRaden PM 2007. Genetic evaluation of stillbirth in United States Holsteins using a sire-maternal grandsire threshold model. Journal of Dairy Science 90, 2480-2488.

Cole JB, Goodling RC Jr, Wiggans GR and VanRaden PM 2005. Genetic evaluation of calving ease for Brown Swiss and Jersey bulls from purebred and crossbred calvings. Journal of Dairy Science 88, 1529-1539.

Cole JB, Waurich B, Wensch-Dorendorf M, Bickhart DM and Swalve HH 2014. A genome-wide association study of calf birth weight in Holstein cattle using single nucleotide polymorphisms and phenotypes predicted from auxiliary traits. Journal of Dairy Science 97, 3156-3172.

Dassonneville R, Baur A, Fritz S, Boichard D and Ducrocq V 2012. Inclusion of cow records in genomic evaluations and impact on bias due to preferential treatment. Genetics Selection Evolution 44, 40.

De Haas Y, Barkema HW and Veerkamp RF 2002. Genetic parameters of pathogenspecific incidence of clinical mastitis in dairy cows. Animal Science 74, 233-242.

De Haas Y, Ouweltjes W, ten Napel J, Windig JJ and de Jong G 2008. Alternative somatic cell count traits as mastitis indicators for genetic selection. Journal Dairy Science 91, 2501-2511.

De Haas $Y$, Windig JJ, Calus MPL, Dijkstra J, de Haan M, Bannink A and Veerkamp RF 2011. Genetic parameters for predicted methane production and potential for reducing enteric emissions through genomic selection. Journal of Dairy Science 94, 6122-6134.

De Haas Y, Calus MP, Veerkamp RF, Wall E, Coffey MP, Daetwyler HD, Hayes BJ and Pryce JE 2012. Improved accuracy of genomic prediction for dry matte intake of dairy cattle from combined European and Australian data sets. Journal Dairy Science 95, 6103-6112.

De Marchi MD, Toffanin V, Cassandro M and Penasa M 2014. Invited review: mid-infrared spectroscopy as phenotyping tool for milk traits. Journal Dairy Science 97, 1-16.

De Mol RM, Andre G, Bleumer JB, van der Werf JTN, de Haas $Y$ and Reenen CG 2013. Applicability of day-to-day variation in behavior for the automated detection of lameness in dairy cows. Journal Dairy Science 96, 3703-3712.

De Passillé AM 2001. Sucking motivation and related problems in calves. Applied Animal Behaviour Science 72, 175-187.

De Rensis F and Scaramuzzi RJ 2003. Heat stress and seasonal effects on reproduction in the dairy cow - a review. Theriogenology 60, 1139-1151.

De Vliegher S, Fox LK, Piepers S, McDougall S and Barkema HW 2012. Invited review: mastitis in dairy heifers: nature of the disease, potential impact, prevention, and control. Journal Dairy Science 95, 1025-1040.

Dehareng F, Delfosse C, Froidmont E, Soyeurt H, Martin C, Gengler N, Vanlierde A and Dardenne P 2012. Potential use of milk mid-infrared spectra to predict individual methane emission of dairy cows. Animal 6, 1694-1701.

Eaglen S, Coffey MP, Wooliams JA and Wall E 2012. Evaluating alternate models to estimate genetic parameters of calving traits in United Kingdom HolsteinFriesian dairy cattle. Genetics Selection Evolution 44, 2. Retrieved 28 March 2014, from http://www.gsejournal.org/content/44/1/23

EFSA-Q-2006-113 2009. Scientific report on the effects of farming systems on dairy cow welfare and disease. European Food Safety Authority. Scientific Report of EFSA Question number:EFSA-Q-2006-113. Retrieved 28 March 2014, from http://www.efsa.europa.eu/en/efsajournal/pub/1143r.htm

Egger-Danner C, Schwarzenbacher H and Willam A 2014. Short communication: genotyping of cows to speed up availability of GEBV for direct health traits in Austrian Fleckvieh (Simmental)cattle - genetic and economic aspects. Journal of Dairy Science 97, 4552-4556.

Egger-Danner C, Willam A, Fuerst C, Schwarzenbacher $\mathrm{H}$ and Fuerst-Waltl B 2012a. Effect of breeding strategies using genomic information on fitness and health. Journal of Dairy Science 95, 4600-4609.

Egger-Danner C, Fuerst-Waltl B, Obritzhauser W, Fuerst C, Schwarzenbacher H Grassauer B, Mayerhofer M and Koeck A 2012b. Recording of direct health traits in Austria-experience report with emphasis on aspects of availability for breeding purposes. Journal of Dairy Science 95, 2765-2777.

Fogh A, Aamand GP, Hjorto L and Lauritsen U 2013. Recording of data and identification issues. ICAR Conference, Aarhus, Denmark. Retrieved 28 March 2014, from http://www.icar.org/documents/aarhus_2013/ Manuscripts/Fogh.pdf
Fritz S, Capitan A, Djari A, Rodriguez SC, Barbat A, Baur A, Grohs C, Weiss B, Boussaha M, Esquerré D, Klopp C, Rocha D and Boichard D 2013. Detection of haplotypes associated with prenatal death in dairy cattle and identification of deleterious mutations in GART, SHBG and SLC37A2. PLoS One 8, e65550.

Fuerst-Waltl B and Fuerst C 2010. Mortality in Austrian dual purpose Fleckvieh calves and heifers. Livestock Science 132, 80-86.

Fuerst-Waltl B and Sorensen MK 2010. Genetic analysis of calf and heifer losses in Danish Holstein. Journal of Dairy Science 93, 5436-5442.

Fuerst-Waltl B, Fuerst C and Egger-Danner C 2012. Claw health diagnoses in the routine health monitoring system of Austrian Fleckvieh cattle. 63rd Annual Meeting of the Association of European Animal Production, 27 August, Bratislava, Slovakia. Retrieved 28 March 2014, from http://www.eaap.org/Previous_Annual_Meetings/ 2012Bratislava/Papers/Published/07_Fuerst-Waltl.pdf

Fuerst-Waltl B, Rinnhofer B, Fuerst C and Winckler C 2010. Genetic parameters for abnormal sucking traits in Austria Fleckvieh heifers. Journal of Animal Breeding and Genetics 127, 113-118.

Fuerst-Waltl B, Egger-Danner C, Zollitsch W and Fuerst-Waltl B 2014. Metabolic disorders and their relationships to milk production traits in Austrian Fleckvieh. Retrieved 9 August, from http://www.icar.org/Documents/Berlin_2014/PPTs/ Presented/Fuerst_Waltl.pdf

Gautam G and Nakao T 2009. Prevalence of urovagina and its effects on reproductive performance in Holstein cows. Theriogenology 71, 1451-1461.

Gengler N 2014. Mitigation strategies versus adaptation strategies. Invited presentation at the ASGGN Workshop. Retrieved 17 August, from http://orbi.ulg. ac.be/bitstream/2268/171555/1/NGENGLER_VF.pdf

Gengler N and Soyeurt H 2010. Interest, recording and possible use of new phenotypes from fine milk composition. Proceedings 9th World Congress of Genetics Applied to Livestock Production, Leipzig, Germany.

Gengler N, Berry DP and Bastin C 2013. Use of automated systems for recording of direct and indirect data with special emphasis on the use of MIR milk spectra (OptiMIR project). Challenges and benefits of health data recording in the context of food chain quality, management and breeding. Proceedings of the ICAR Health Data Conference, 30-31 May 2013, Aarhus, Denmark. ICAR Technical Series no. 17, pp. 55-61.

Gernand E, Rehbaein P, von Borstel UU and König S 2012. Incidences of and genetic parameters for mastitis, claw disorders, and common health traits recorded in dairy cattle contract herds. Journal of Dairy Science 95, 2144-2156. Giuliana GM-P, Kaler J, Remnant J, Cheyne L, Abbott C, French AP, Pridmore TP and Huxley JN 2014. Behavioural changes in dairy cows with lameness in an automatic milking system. Applied Animal Behavioural Science 150, 1-8.

Gonzalez-Recio 0, Pryce JE, Haile-Mariam M and Hayes BJ 2014a. Incorporating heifer feed efficiency in the Australian selection index using genomic selection. Journal of Dairy Science 97, 3883-3893.

Gonzalez-Recio 0, Coffey MP and Pryce JE 2014b. On the value of phenotypes in the genomic era. Journal of Dairy Science (in press).

Govignon-Gion A, Dassonneville R, Baloche G and Ducrocq V 2012. Genetic evaluation of mastitis in dairy cattle in France. Interbull Bulletin 46, Retrieved 28 March 2014, from https://journal.interbull.org/index.php/ib/article/view/1276

Häggmann J and Juga J 2013. Genetic parameters for hoof disorders and feet and leg conformation traits in Finnish Holstein cows. Journal of Dairy Science 96 3319-3325.

Haugaard K, Heringstad B and Whist AC 2012. Genetic analysis of pathogenspecific clinical mastitis in Norwegian Red cows. Journal of Dairy Science 95, 1545-1551.

Haugaard K, Svendsen M and Heringstad B 2014. Genomic predictions of fertility related disorders in Norwegian Red using 30 years of data. Proceedings 10th World Congress of Genetics Applied to Livestock Production, Vancouver, Canada.

Haussermann A and Hartung E 2012. Detection of mastitis during milking current solutions and prospective ideas. 63rd Annual Meeting of the Association of European Animal Production, 27 August, Bratislava, Slovakia. Retrieved 28 March 2014, from http://www.eaap.org/Previous_Annual_Meetings/2012 Bratislava/Papers/Published/07_Haeussermann.pdf

Hegarty RS, Goopy JP, Herd RM and McCorkell B 2007. Cattle selected for lower residual feed intake have reduced daily methan production. Journal of Animal Science 85, 1479-1486.

Heringstad B, 2010. Genetic analysis of fertility related diseases and disorders in Norwegian Red cows. Journal of Dairy Science 93, 2751-2756. 
Heringstad B and Østerås 0 2013. More than 30 years of health recording in Norway. ICAR 2013 Health Data Conference: challenges and benefits of health data recording in the context of food chain quality, management and breeding 30-31 May 2013, Århus, Denmark.

Heringstad B and Bugten HK 2014. Genetic evaluations of milkability in Norwegian Red based on data from Automatic Milking Systems. Proceedings 10th World Congress of Genetics Applied to Livestock Production, Vancouver, Canada.

Heringstad B, Klemetsdal G and Steine T 2007. Selection responses for disease resistance in two selection experiments with Norwegian red cows. Journal of Dairy Science 90, 2419-2426.

Heringstad B, Chang YM, Gianola D and Klemetsdal G 2004. Multivariate threshold model analysis of clinical mastitis in multiparous Norwegian dairy cattle. Journal of Dairy Science 87, 3038-3046.

Heringstad B, Chang YM, Gianola D and Klemetsdal G 2005. Genetic analysis of clinical mastitis, milk fever, ketosis, and retained placenta in three lactations of norwegian red cows. Journal of Dairy Science 88, 3273-3281.

Heringstad B, Chang YM, Gianola D and Østerås 0 2008. Short communication: genetic analysis of respiratory disease in Norwegian Red calves. Journal of Dairy Science 91, 367-370.

Heringstad B, Gianola D, Chang YM, Ødegård J and Klemetsdal G 2006. Genetic associations between clinical mastitis and somatic cell score in early firstlactation cows. Journal of Dairy Science 89, 2236-2244.

Heringstad B, Su G, Solberg TR, Guldbrandtsen B, Svendsen M and Lund MS 2011. Genomic predictions based on a joint reference population for Scandinavian red breeds. 62nd Annual Meeting of the Association of European Animal Production, 29 August. Retrieved 6 September 2014, from http://www.eaap.org/ Previous_Annual_Meetings/2011Stavanger/Papers/Published/S04_Heringstad.pdf ICAR 2012. ICAR guidelines for recording, evaluation and genetic improvement of health traits. Retrieved 10 December 2013, from http://www.icar.org/ Documents/Rules\%20and\%20regulations/Amendments\%202012/Recording, $\% 20$ Evaluation $\% 20$ and $\% 20$ Genetic $\% 20$ Improvement $\% 20$ of $\% 2$ health $\% 20$ traits. pdf

ICAR 2013. Challenges and benefits of health data recording in the context of food chain quality, management and breeding. ICAR Technical Series no. 17. Retrieved 25 March 2014, from http://www.icar.org/Documents/technical_ series/tec_series_17_Aarhus.pdf

ICAR 2014. ICAR guidelines for recording, evaluation and genetic improvement of female fertility in dairy cattle. Retrieved 24 January 2014, from http:// www.icar.org/Documents/Rules\%20and\%20regulations/Guidelines/Guidelines_ Female_Fertility_for_approval.pdf

Ikonen T, Ahlfors K, Kempe R, Ojala M and Ruottinen 0 1999. Genetic parameters for the milk coagulation properties and prevalence of noncoagulating milk in Finnish dairy cows. Journal of Dairy Science 82, 205-214.

Ikonen T, Morri S, Tyrisevä A-M, Ruottinen 0 and Ojala M 2004. Genetic and phenotypic correlations between milk coagulation properties, milk production traits, somatic cell count, casein content, and pH of milk. Journal of Dairy Science 87, 458-467.

Interbull 2013. National genetic evaluation forms provided by country. http:// www.interbull.org/ib/geforms

Jimenez-Montero JA, Gonzales-Rezio 0 and Alenda R 2012. Genotyping strategies for genomic selection in small dairy cattle populations. Animal 6, 1216-1224.

Johansson K, Eriksson J-Å, Nielsen US, Pösö J and Aamand GP 2011. Genetic evaluation of claw health in Denmark, Finland and Sweden. Interbull Bulletin 44, 224-228.

Jones WP, Hansen LB and Chester-Jones H 1994. Response of health care to selection for milk yield of dairy cattle. Journal of Dairy Science 77, 3137-3152.

Jonker JS, Kohn RA and Erdman RA 1998. Using milk urea nitrogen to predict nitrogen excretion and utilization efficiency in lactating dairy cows. Journal of Dairy Science 81, 2681-2692.

Juga J 1996. Evaluation methods of subjectively scored functional traits in Finland. Interbull Bulletin 14, 155-160.

Kadri NK, Sahana G, Charlier C, Iso-Touru T, Guldbrandtsen B, Karim L, Nielsen US, Panitz F, Aamand GP, Schulman N, Georges M, Vilkki J, Lund MS and Druet T 2014. A 660-Kb deletion with antagonistic effects on fertility and milk production segregates at high frequency in Nordic Red cattle: additional evidence for the common occurrence of balancing selection in livestock. PLoS Genetics 10 e1004049.
Kadzere CT, Murphy MR, Silanikove N and Maltz E 2002. Heat stress in lactating dairy cows: a review. Livestock Production Science 77, 59-91.

Kandel PB, Vanrobays ML, Vanlierde A, Dehareng F, Froidmont E, Dardenne $P$, Lewis E, Buckley F, Deighton MH, McParland S, Gengler N and Soyeurt H 2013. Genetic parameters for methane emission predicted from milk mid-infrared spectra in dairy cows. Advances in Animal Biosciences 4, 279.

Koeck A, Miglior F, Jamrozik J, Kelton DF and Schenkel FS 2013. Genetic associations of ketosis and displaced abomasum with milk production traits in early first lactation of Canadian Holsteins. Journal of Dairy Science 96, 4688-4696.

Koeck A, Heringstad B, Egger-Danner C, Fuerst C, Winter P and Fuerst-Waltl B 2010a. Genetic analysis of clinical mastitis and somatic cell count traits in Austrian Fleckvieh cows. Journal of Dairy Science 93, 5987-5995.

Koeck A, Egger-Danner C, Fuerst W, Obritzhauser W and Fuerst-Waltl B $2010 \mathrm{~b}$. Genetic analyses of reproductive disorders and their relationship to fertility and milk yield in Austrian Fleckvieh dual-purpose cows. Journal of Dairy Science 93, 2185-2194.

Koeck A, Loker S, Miglior F, Kelton DF, Jamrozik J and Schenkel FS 2014. Genetic relationships of clinical mastitis, cystic ovaries, and lamness with milk yield and somatic cell score in first-lactation Canadian Holsteins. Journal of Dairy Science 97, 1-8.

Koenig S and Swalve HH 2006. Modelkalkulationen zu zuechterischen moeglichkeiten auf klauengesundheit beim milchrind. Züchtungskunde 78, 345-356.

Koenig S, Köhn F, Kuwan K, Simianer H and Gauly M 2006. Use of repeated measures analysis for evaluation of genetic background of dairy cattle behavior in automatic milking systems. Journal of Dairy Science 89 3636-3644.

Koenig S, Scharifi AR, Wentrot $H$, Landmann D, Eise M and Simianer H 2005. Genetic parameters of claw and foot disorders estimated with logistic models. Journal of Dairy Science 88, 3316-3325.

Kofler J 2013. Computerised claw trimming database programs as the basis for monitoring hoof health in dairy herds. Veterinary Journal 198, 358-361.

Kramer M, Erbe M, Bapst B, Bieber A and Simianer H 2013. Estimation of genetic parameters for novel functional traits in Brown Swiss cattle. Journal of Dairy Science 96, 1-11.

Lewis S, Handy RD, Cordi B, Billinghurst Z and Depledge MH 1999. Stress proteins (HSP's): methods of detection and their use as an environmental biomarker. Ecotoxicology 8, 351-368.

Linde C, de Jong G, Koenen DPC, Eding H 2010. Claw health index for Dutch dairy cattle based on claw trimming and conformation data. Journal Dairy Science 93, 4883-4891.

Lovendahl P and Chagunda MG 2010. On the use of physical activity monitoring for estrus detection in dairy cows. Journal of Dairy Science 93, 249-259.

Lovendahl P, Lassen J and Chagunda MG 2012. Genetic variation in milking efficiency: a novel trait for milkability in automatic milking systems. 63rd Annual Meeting of the Association of European Animal Production, 27 August, Bratislava, Slovakia. Retrieved 28 January 2014, from http://www.eaap.org/ Previous_AnnualMeetings/2012Bratislava/Papers/Published/22Lovendahl.pdf

Lucy MC 2001. Reproductive loss in high-producing dairy cattle: where will it end? Journal of Dairy Science 84, 1277-1293.

Margerison JK, Preston TR, Berry N and Phillips CJC 2003. Cross-sucking and other oral behaviours in calves, and their relation to cow suckling and food provision. Applied Animal Behaviour Science 80, 277-286.

McClure MC, Bickhart D, Null D, VanRaden $P, X u$ L, Wiggans G, Liu G, Schroeder S, Glasscock J, Armstrong J, Cole JB, Van Tassell CP and Sonstegard TS 2014. Bovine exome sequence analysis and targeted SNP genotyping of recessive fertility defects $\mathrm{BH} 1, \mathrm{HH} 2$, and $\mathrm{HH} 3$ reveal a putative causative mutation in SMC2 for HH3. PLoS One 9(3), e92769. doi: 10.1371/journal. pone.0092769.

McCorquodale CE, Sewalem A, Miglior F, Kelton DF, Robinson A, Koeck A and Leslie KE 2013. Analysis of health and survival in a population of Ontario Holstein heifer calves. Journal of Dairy Science 96, 1880-1885.

McParland S, Banos G, Wall E, Coffey MP, Soyeurt H, Veerkamp RF and Berry DP 2011. The use of mid-infrared spectrometry to predict body energy status of Holstein cows. Journal of Dairy Science 94, 3651-3661.

McParland S, Lewis E, Kennedy E, Moore S, McCarthy B, O'Donovan M, Butler S, Pryce JE and Berry D 2014. Mid-infrared spectrometry of milk as a predictor of energy intake and efficiency in lactating dairy cows. Journal of Dairy Science 97, 5863-5871. 
Melzer N, Wittenburg D, Harwig S, Jakubwoski S, Kesting U, Willmitzer L, Lisec J Reinsch N and Repsilber D 2013. Investigating associations between milk metabolite profiles and milk traits of Holstein cows. Journal of Dairy Science 96, 1521-1534.

Meuwissen THE, Hayes BJ and Goddard ME 2013. Accelerating improvement of livestock with genomic selection. Annual Review of Animal Biosciences 1 221-237.

Miglior F, Chesnais J and Van Doormaal BJ 2012. Genetic improvement: a major component of increased dairy farm profitability. Retrieved March 28, 2014, from http://www.icar.org/cork_2012/Manuscripts/Published/Miglior\%20A1.pdf

Mohammed R, McGinn SM and Beauchemin KA 2011. Prediction of enteric methane output from milk fatty acid concentrations and rumen fermentation parameters in dairy cows fed sunflower, flax, or canola seeds. Journal of Dairy Science 94, 6057-6068.

Mousa MS, Seykora AJ, Chester-Jones H, Ziegler DM and Cole JB 2013. Heritability estimates of performance and health traits of Holstein calves. Journal of Dairy Science 96 (suppl. 2), 291. (abstract W194).

NAV Routine Evaluation 2014. Nordic cattle genetic evaluation. Retrieved 18 August 2014, from http://www.nordicebv.info/News/NewsNAVRoutineEvaluation August12th2014.htm?wbc_purpose=Basic\&WBCMODE=PresentationUnpublished? Mode=Print\&Site=DLINavSkin1

Negussie E, Strandén I and Mäntysaari EA 2008. Genetic association of clinical mastitis with test-day somatic cell score and milk yield during first lactation of Finnish Ayrshire cows. Journal of Dairy Science 91, 1189-1197.

Negussie E, Stranden I and Mäntysaari EA 2013. Genetic associations of test-day fat:protein ratio with milk yield, fertility, and udder health traits in Nordic Red cattle. Journal of Dairy Science 96, 1237-1250.

Nicolazzi E, Biscarini F and Stella A and ProZoo team 2012. Automated milk-recording systems: an experience in Italian dairy cattle farms. 63rd Annual Meeting of the Association of European Animal Production, August, Bratislava, Slovakia. Retrieved 20 December 2014, from http://www. eaap.org/Previous_Annual_Meetings/2012Bratislava/Papers/Published/12 Biscarini.pdf

Nkrumah JD, Okine EK, Mathison GW, Schmid K, Li C, Basarab JA, Price MA, Wang Z and Moore SS 2006. Relationships of feedlot feed efficiency, performance, and feeding behavior with metabolic rate, methane production, and energy partitioning in beef cattle. Journal of Animal Science 84, 145-153.

Norberg E 2005. Electrical conductivity of milk as a phenotypic and genetic indicator of bovine mastitis: a review. Livestock Production Science 96 129-139.

Ødegård C, Svendsen M and Heringstad B 2013. Genetic correlations between claw health and feet and leg conformation in Norwegian Red cows. Journal of Dairy Science 97, 4522-4529.

Ødegård C, Svendsen M and Heringstad B 2014. Accuracy of genomic breeding values for corkscrew claw in Norwegian Red. Proceedings 10th World Congress of Genetics Applied to Livestock Production, Vancouver, Canada.

Østerås 0, Solbu H, Refsdal AO, Roalkvan T, Filseth 0 and Minsaas A 2007. Results and evaluation of thirty years of health recordings in the Norwegian dairy cattle population. Journal of Dairy Science 90, 4483-4497.

Parker Gaddis KL, Cole JB, Clay JS and Maltecca C 2012. Incidence validation and causal relationship analysis of producer-recorded health event data from on-farm computer systems in the U.S. Journal of Dairy Science 95, 5422-5435

Parker Gaddis KL, Cole JB, Clay JS and Maltecca C 2014. Genomic selection for producer-recorded health event data in US dairy cattle. Journal of Dairy Science 97, 3190-3199.

Pausch H, Schwarzenbacher H, Burgstaller J, Flisikowski K, Wurmser C, Jansen S, Schnieke A, Wittek T and Fries R 2014a. Homozygous haplotype deficiency reveals deleterious mutations compromising reproductive and rearing success in cattle. Submitted in September 2014.

Pausch $H$, Kölle $S$, Wurmser $C$, Schwarzenbacher $H$, Emmerling $R$, Jansen $S$, Trottmann M, Fuerst C, Götz K and Fries R 2014b. A nonsense mutation in TMEM95 endcoding a nondscript transmembrane protein causes idiophathic male subfertility in cattle. PLoS Genetics (submitted).

Pavon S 2013. Future challenges concerning animal breeding and consumer protection (regulations of interest for this topics and expected developments). ICAR 2013 Health Data Conference, 30-31 May, Århus, Denmark. Retrieved 20 March 2014, from http://www.icar.org/documents/aarhus_2013/powerpoint/ HealthConference/Session1/Pavon.pdf
Polat B, Colak A, Gengiz M, Yanmaz LE, Oral H, Bastan A, Kaya S and Hayirli A 2010. Sensitivity and specificity of infrared thermography in detection of sublinical mastitis in dairy cows. Journal of Dairy Science 93, 3525-3532.

Povinelli M, Gallo L, Carnier P, Marcomin D, Zotto RD and Cassandro M 2005. Genetic aspects of milk electrical conductivity in Italian Brown cattle. Italian Journal of Animal Science 4 (suppl. 3), 169-171.

Pryce JE and Berry DP 2014. Genomic breeding values for novel traits such as feed efficiency through female only reference populations. ICAR Conference Berlin, 19-23 May, Berlin, Germany.

Pryce JE, Coffey MP and Simm G 2001. The relationship between body condition score and reproductive performance. Journal of Dairy Science 84, 1508-1515.

Pryce JE, Wales WJ, de Haas Y, Veerkamp RF and Hayes BJ 2014a. Genomic selection for feed efficiency in dairy cattle. Animal 8, 1-10.

Pryce JE, Gonzalez-Recio 0, Thornhill JB, Marett LC, Wales WJ, Coffey MP, de Haas Y, Veerkamp RF, Hayes BJ 2014b. Short communication: validation of genomic breeding value predictions for feed intake and feed efficiency traits. Journal of Dairy Science 97, 537-542.

Pryce JE, Esslemont RJ, Thompson R, Veerkamp RF, Kossaibati MA and Simm G 1998. Estimation of genetic parameters using data from a health and fertility management recording system. Animal Science 66, 577-584.

Pszczola M, Strabel T, Mulder HA and Calus M 2012. Reliability of direct genomic values for animals with different relationships within and to the reference population. Journal of Dairy Science 95, 389-400.

Pszczola M, Veerkamp RF, de Haas Y, Wall E, Strabel T and Calus M 2013. Effect of predictor traits on accuracy of genomic breeding values for feed intake based on a limited cow reference population. Animal 7, 1759-1768.

Rinell E 2013. A genetic analysis of traits recorded by automatic milking systems the possibility for a new method to evaluate temperament of dairy cows. Master's Thesis, 30 HEC. Swedish University of Agricultural Sciences, Department of Animal Breeding and Genetics, Uppsala, 420pp.

Roberts T, Chapinal N, LeBlanc SJ, Kelton DF, Dubuc J and Duffield TF 2012. Metabolic parameters in transition cows as indicators for early-lactation culling risk. Journal of Dairy Science 95, 3057-3063.

Roche JR, Friggens NC, Kay JK, Fischer MW, Stafford KJ and Berry DP 2010. Invited review: body condition score and its association with dairy cow productivity, health and welfare. Journal of Dairy Science 92, 5769-5801.

Roessler R, Herold P, Weidele A and Zarate AV 2013. Definition nutzerspezifischer Zuchtziele für Braunvieh und Hinterwälder Rind in Baden-Württemberg. Züchtungskunde 3, 173-187.

Ross EM, Moate PJ, Marett LC, Cocks BG and Hayes BJ 2013. Metagenomic predictions: from microbiome to complex health and environmental phenotypes in humans and cattle. PLoS One 9, e92769.

Rutten CJ, Velthuis AGJ, Steeneveld W and Hogeveen H 2013. Invited review: sensors to support health management on dairy farms. Journal of Dairy Science 96, 1928-1952.

Schöpke K and Weigel K 2014. Use of accelerometer data for genetic evaluation in dairy cattle. Interbull Open Meeting Berlin. Retrieved on 21 August 2014, from http://www.interbull.org/web/static/presentations/Berlin/Tuesday/ 12_18_Schoepke.pdf

Schwarzenbacher H 2013. Survey within Gene2Farm.Gene2Farm 2014. Next generation European system for cattle improvement and management (EU-FP7 KBBE-2011-5-PNr.:289592). Project from the 7th Framework Program. Retrieved 28 March 2014, from http://www.gene2farm.eu

Schwarzenbacher H, Fuerst C, Fuerst-Waltl B and Dolezal M 2012. A genomewide search for harmful recessive haplotypes in Brown Swiss and Fleckvieh cattle. 63rd Annual Meeting of the Association of European Animal Production, 27 August, Bratislava, Slovakia. Retrieved 6 September 2014 from http://www.eaap.org/Previous_Annual_Meetings/2012Bratislava/Papers/ Published/22_Schwarzenbacher.pdf

Smit B, Burton I, Klein RJT and Street R 1999. The science of adaptation: a framework for assessment. Mitigation and Adaptation Strategies for Global Change 4, 199-213.

Sonstegard TS, Cole JB, VanRaden PM, Van Tassell CP, Null DJ, Schroeder SG, Bickhart D and McClure MC 2013. Identification of a nonsense mutation in CWC15 associated with decreased reproductive efficiency in Jersey cattle. PLoS One 8, e54872.

Sorenson LP, Madsen P, Mark T and Lund MS 2009. Genetic parameters for pathogen-specific mastitis resistance in Danish Holstein Cattle. Animal 3, 647-656. 
Soyeurt H, Bruwier D, Romnee JM, Gengler N, Bertozzi C, Veselko D and Dardenne P 2009. Potential estimation of major mineral contents in cow milk using mid-infrared spectrometry. Journal of Dairy Science 92, 2444-2454.

Soyeurt H, Dehareng F, Gengler N, McParland S, Wall E, Berry DP, Coffey M and Dardenne P 2011. Mid-infrared prediction of bovine milk fatty acids across multiple breeds, production systems, and countries. Journal of Dairy Science 94, 1657-1667.

Soyeurt H, Bastin C, Colinet FG, Arnould VMR, Berry DP, Wall E, Dehareng F, Nguyen HN, Dardenne P, Schefers J, Vandenplas J, Weigel K, Coffey M, Théron L, Detilleux J, Reding E, Gengler N and McParland S 2012a. Mid-infrared prediction of lactoferrin content in bovine milk: potential indicator of mastitis. Animal 6, 1830-1838.

Soyeurt H, Dehareng F, Gengler N and Dardenne P 2012b. Capitalizing on mid-infrared to improve nutritional and environmental quality of milk. World Holstein Conference, Toronto, Canada. Retrieved 20 February 2014, from http:/ www.whff.info/info/documents/17_NicolasGengler.pdf

Soyeurt H, Dehareng F, Romnée JM, Gengler N and Dardenne P 2012c. Genetics of the mineral contents in bovine milk predicted by mid-infrared spectrometry. 63rd Annual Meeting of the Association of European Animal Production, 27 August, Bratislava, Slovakia. Retrieved 28 March 2014, from http://www.eaap.org/ Previous_Annual_Meetings/2012Bratislava/Papers/Published/03_Soyeurt.pdf

Stege H, Bager F, Jacobsen E and Thougaard A 2003. VETSTAT - the Danish system for surveillance of the veterinary use of drugs for production animals. Preventive Veterinary Medicine 57, 105-115.

Steininger F, Fuerst-Waltl B, Pfeiffer C, Fuerst C, Schwarzenbacher $\mathrm{H}$ and EggerDanner C 2012. Participatory development of breeding goals in Austrian dairy cattle. Acta Agriculturae Slovenica 01/2012 (suppl. 3), 143-147.

Stock KF, Agena D, Schafberg R and Reinhardt F 2013. Health monitoring concepts for long-term improvement of dairy health. 64th Annual Meeting of the Association of European Animal Production, 26-30 August, Nantes, France. Abstract 17060.

Stock KF, Cole J, Pryce J, Gengler N, Bradley A, Andrews L and Egger-Danner C 2012. Survey on the recording and use of functional traits in dairy management and breeding. Proceedings ICAR Annual Meeting, 30 May, Cork/Ireland.

Thom EC 1959. The discomfort index. Weatherwise 12, 57-60.

Thomasen JR, Sorensen AC, Lund MS and Guldbrandtsen B 2014. Adding cows to the reference population makes a small dairy population competitive. Journal of Dairy Science 97, 1-11.

United Nations 2014. World population projected to reach 9.6 billion by $2050-$ UN report. Retrieved 13 March 2014, from http://www.un.org/apps/news/story. asp?News ID $=45165$
Urioste Jl, Franzen J and Strandberg E 2010. Phenotypic and genetic characterization of novel somatic cell count traits from weekly and monthly observations. Journal of Dairy Science 93, 5930-5941.

Urioste JI, Franzen J, Windig JJ and Strandberg E 2012. Genetic relationships among mastitis and alternative somatic cell count traits in the first 3 lactations of Swedish Hosteins. Journal of Dairy Science 95, 3428-3434.

Van der Drift SGA, Jorritsma R, Schonewille JT, Kmnijn HM and Stegeman JA 2012. Routine detection of hyperketonemia in dairy cows using Fourier transform infrared spectroscopy analysis of ß-hydroxybutyrate and acetone in milk in combination with test-day information. Journal of Dairy Science 95, 4886-4898.

VanRaden PM, Olson KM, Null DJ and Hutchison JL 2011. Harmful recessive effects on fertility detected by absence of homozygous haplotypes. Journal of Dairy Science 94, 6153-6161.

Von Keyserlingk MAG, Rushen J, de Passillé AM and Weary DM 2009. Invited review: the welfare of dairy cattle - key concepts and the role of science. Journal of Dairy Science 92, 4101-4111.

Walthall $C L$, Hatfield J, Backlund $P$, Lengnick $L$, Marshall E, Walsh M, Adkins S, Aillery $\mathrm{M}$, Ainsworth EA, Ammann $\mathrm{C}$, Anderson $\mathrm{CJ}$, Bartomeus I, Baumgard $\mathrm{LH}$, Booker F, Bradley B, Blumenthal DM, Bunce J, Burkey K, Dabney SM, Delgado JA, Dukes J, Funk A, Garrett K, Glenn M, Grantz DA, Goodrich D, Hu S, Izaurralde RC, Jones RAC, Kim S-H, Leaky ADB, Lewers K, Mader TA, McClung A, Morgan J, Muth DJ, Nearing M, Oosterhuis DM, Ort D, Parmesan C, Pettigrew WT, Polley W, Rader R, Rice C, Rivington M, Rosskopf E, Salas WA, Sollenberger LE, Srygley R Stöckle C, Takle ES, Timlin D, White JW, Winfree R, Wright-Morton L, Ziska LH 2012. Climate change and agriculture in the United States: effects and adaptation. USDA Technical Bulletin 1935, Washington, DC. Retrieved 28 March 2014, from http://www.usda.gov/oce/climate_change/effects.htm

Weber A, Stamer E, Junge W and Thaller G 2013. Genetic parameters for lameness and claw and leg diseases in dairy cows. Journal of Dairy Science 96, 3310-3318. West JW 2003. Effects of heat-stress on production in dairy cattle. Journal of Dairy Science 86, 2131-2144.

Wiggans GR, VanRaden PM and Cooper TA 2012. Technical note: adjustment of all cow evaluations for yield traits to be comparable with bull evaluations. Journal of Dairy Science 95, 3444-3447.

Wiggans GR, Cooper TA, VanRaden PM and Cole JB 2011. Technical note: adjustment of traditional cow evaluations to improve accuracy of genomic predictions. Journal of Dairy Science 94, 6188-6193.

Yao C, Weigel KA and Cole JB 2014. Short communication: genetic evaluation of stillbirth in US Brown Swiss and Jersey cattle. Journal of Dairy Science 97, 2474-2480.

ZuchtData 2014. Yearly report 2013, Vienna, Austria. Retrieved 9 August 2014 from http://zar.at/Downloads/Jahresberichte/ZuchtData-Jahresberichte.htm 